\title{
International changes in end-of-life practices over time: a systematic review
}

Yi-Sheng Chao ${ }^{1}$, Antoine Boivin ${ }^{1,2^{*}}$, Isabelle Marcoux ${ }^{3}$, Geneviève Garnon ${ }^{4}$, Nicholas Mays ${ }^{5}$, Pascale Lehoux ${ }^{6}$, Marie-Claude Prémont ${ }^{7}$, Evert van Leeuwen ${ }^{8}$ and Raynald Pineault ${ }^{9}$

\begin{abstract}
Background: End-of-life policies are hotly debated in many countries, with international evidence frequently used to support or oppose legal reforms. Existing reviews are limited by their focus on specific practices or selected jurisdictions. The objective is to review international time trends in end-of-life practices.

Methods: We conducted a systematic review of empirical studies on medical end-of-life practices, including treatment withdrawal, the use of drugs for symptom management, and the intentional use of lethal drugs. A search strategy was conducted in MEDLINE, EMBASE, Web of Science, Sociological Abstracts, PAIS International, Worldwide Political Science Abstracts, International Bibliography of the Social Sciences and CINAHL. We included studies that described physicians' actual practices and estimated annual frequency at the jurisdictional level. End-of-life practice frequencies were analyzed for variations over time, using logit regression.
\end{abstract}

Results: Among 8183 references, 39 jurisdiction-wide surveys conducted between 1990 and 2010 were identified. Of those, 22 surveys used sufficiently similar research methods to allow further statistical analysis. Significant differences were found across surveys in the frequency of treatment withdrawal, use of opiates or sedatives and the intentional use of lethal drugs $\left(X^{2}>1000, p<0.001\right.$ for all). Regression analyses showed increased use of opiates and sedatives over time $(p<0.001)$, which could reflect more intense symptom management at the end of life, or increase in these drugs to intentionally cause patients' death.

Conclusion: The use of opiates and sedatives appears to have significantly increased over time between 1990 and 2010. Better distinction between practices with different legal status is required to properly interpret the policy significance of these changes. Research on the effects of public policies should take a comprehensive look at trends in end-of-life practice patterns and their associations with policy changes.

Keywords: End-of-life practice, Treatment withdrawal, Aid in dying, Assisted suicide, Euthanasia

\footnotetext{
*Correspondence: antoine.boivin@umontreal.ca

'University of Montreal Hospital Centre Research Centre (CRCHUM), Montreal,

Canada

${ }^{2}$ Institut de recherche en santé publique de l'Université de Montréal,

Montréal, Canada

Full list of author information is available at the end of the article
} 


\section{Background}

End-of-life policies are hotly debated in many countries, with international evidence used to support or oppose legal reforms [1-3]. For example, recent policy proposals on the legalization of "medical aid in dying", "physicianassisted suicide" and "euthanasia" in Canada, the United Kingdom, and France have made frequent references to empirical research from other countries [4, 5].

A scoping review highlighted the need to take a comprehensive look at international end-of-life practice variations, because existing reviews tended to focus on specific practices or selected countries [6]. More specifically, trends in patterns of "euthanasia" and "assisted suicide" are most frequently discussed, with less attention being put on treatment withdrawal and the use of drugs for symptom management [7-11]. This could be problematic as it limits the ability to study the effects of public policies on the full range of end-of-life practices.
Also, changes in a single jurisdiction might reflect global trends in end-of-life practices, rather than domestic patterns.

\section{Objective}

The goal of this research was to systematically review international time trends in end-of-life practices.

\section{Methods}

Design

We conducted a systematic review of empirical studies on medical end-of-life practices (see Fig. 1 for the flowchart).

\section{Definitions and classification of end-of-life practices}

Definitions and labelling of medical end-of-life practices vary and no consensus exists on terminology at the international level. For example, definitions of

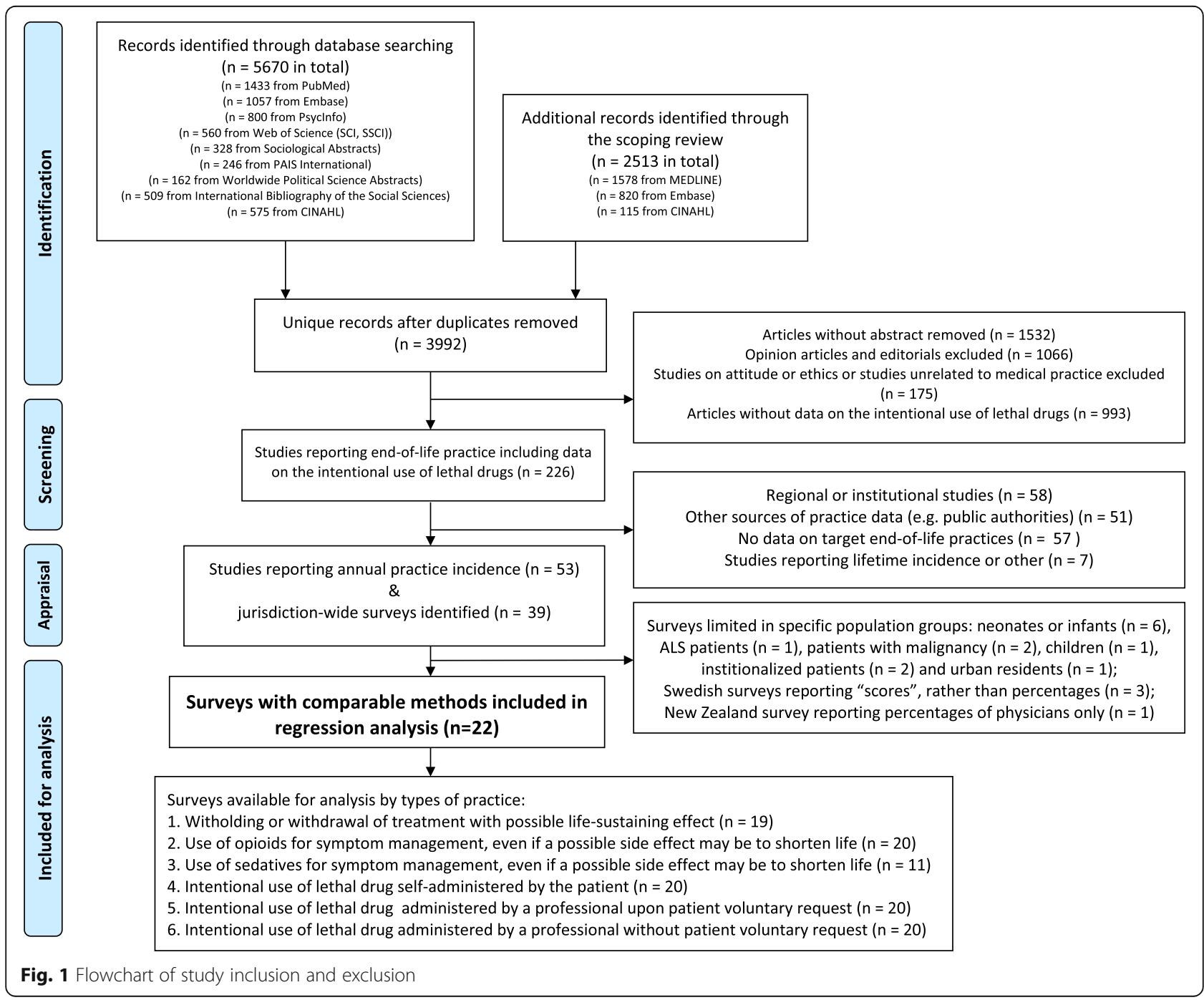


"euthanasia" have evolved over time and across jurisdictions [12, 13]. For these reasons, we developed a descriptive classification of medical end-of-life practices. The classification is based on observable medical behaviors that can be studied empirically, and distinguishes practices with different legal status across jurisdictions, including:

1. Withdrawing or withholding of treatments that have the potential to prolong life;

2. Use of drugs for symptom management even if an unintended side-effect may be to shorten life;

3. Intentional use of a lethal drug.

The classification further distinguishes whether endof-life practices are carried out: a) with a voluntary and informed request made by the patient; b) with a voluntary advanced directive made by a previously competent patient, c) with a substitute request by the proxy decision-maker of an incompetent patient; or d) without a patient or substitute request. We also distinguish whether lethal drugs are administered by patients or by someone else.

Testing of this classification in a scoping review allowed for the translation of different end-of-life practice definitions into comparable categories, despite variations in labeling and definitions used in the original studies [6].

\section{Inclusion criteria}

To be included, articles written in English or French needed to: 1) report on physicians' actual end-of-life practices (rather than their opinions and attitudes); 2) include data on treatment withholding/withdrawal, use of drugs for symptom management, and the intentional use of lethal drugs; 3) allow estimates of annual practice frequency at the jurisdictional level. We excluded articles limited to specific populations (e.g. neonates) or practice settings (e.g. nursing homes). We also excluded articles using physicians' self-reporting of end-of-life practices to public regulatory authorities (e.g. euthanasia review committees) as this data source would not allow comparisons across jurisdictions with different legislative frameworks and would not provide information on some categories of practices included in our classification (e.g. intentional use of lethal drugs without patient request).

\section{Search strategy}

The literature databases searched were: MEDLINE, Embase, PsycInfo, Web of Science (SCI, SSCI), Sociological Abstracts, EMBASE, PAIS International, Worldwide Political Science Abstracts, International
Bibliography of the Social Sciences and CINAHL. Search terms are listed in Appendix 1. The literature was searched in April 2014 and were pooled with articles identified in a previous scoping review that also included grey literature and online publications [6].

\section{Data screening and extraction}

Two reviewers separately screened each article and any discrepancies regarding the inclusion or exclusion of articles were resolved in team meetings. The information and statistics on these articles were extracted by one of two assistants and two review authors, verified by one of the review authors (GG or YSC), and entered in a FileMaker Pro v. 13 database developed with an information technology specialist. The items extracted from articles included year of publication, authors, title, abstract, source database, the types of end-of-life practice studied, funding sources, types of study (qualitative, quantitative or mixed), characteristics of study participants, and affiliations of first authors. When the same survey was reported in multiple articles, an index article was used to extract information on data collection methods (including duration, population groups and region of study), response rates, selective reporting for outcomes, details in statistical procedures, total numbers of deaths and summary percentages of end-of-life practices in each jurisdiction.

\section{Comparability of study methods and risk of bias}

The objectives for assessing the risk of bias were to 1) identify the risk of bias in estimated frequencies; 2) understand the heterogeneity of study methods to identify a subset of comparable studies using similar reference populations and outcome measures. We used quality appraisal criteria designed for systematic reviews $[14,15]$ and observational studies $[16,17]$. The assessment criteria were: background information (population coverage, number of studied deaths, total number of deaths in the jurisdiction) [18]; basic survey information (article types, study design, author affiliations) [16]; design-specific assessment (statistical, conflict of interest, response rate, frequency of measurement, sample sizes, methods to adjust for selection bias) [19-21]; and practice-related assessment (methods for measuring outcome variables and selective outcome reporting) [22]. After reviewing the included surveys, the comparability of study design and statistical methods were assessed in the team meetings. Surveys using comparable methods (population characteristics, questionnaire types, statistical methods, and reporting methods) were retained for regression analysis. 


\section{Data analysis}

The main outcome measure was the annual frequency of end-of-life practices as a percentage (\%) of all deaths [7]. We further collected the $95 \%$ confidence intervals (CIs) of the weighted frequencies or the nominators and denominators of the reported frequencies.

The extracted data were analyzed with $\mathrm{R}$ programming languange and RStudio (version 0.98.1091, RStudio Inc.). The surveys that adopted multiple-stage sampling usually provided the mean percentages of end-of-life practice with $95 \%$ CIs. The comparisons of the percentages of end-of-life practices across jurisdictions were carried out using Chi-squared tests. If Chi-squared tests were not appropriate, simulation was used [23].

The relationships between the frequencies of endof-life practices and time (year of data collection) were assumed to be linear and were analyzed with logit regression. The null hypotheses were that there were no associations between the frequencies and time (regression coefficients of time equal to zero). Jurisdictions or survey types that were found to be significantly associated with different levels of endof-life practice frequencies [7] were adjusted in models that included all eligible surveys. Due to the variability originating from stratified sampling and adjustment for non-response, the $95 \%$ CIs of reported frequencies were taken into account using simulations. The mean percentages were used to draw the regression lines in the graphs. The magnitudes of change in end-of-life practices from all included surveys were estimated with the differences in the predicted frequencies of the Dutch death certificate surveys from 1990 (or 2001 for use of sedatives for symptom management) to 2010 based on the regression models that included all surveys, since the Dutch surveys were the only ones to have been implemented throughout the period. The Dutch and Belgian surveys were also analyzed with separate regression models.

\section{Results}

Among 8183 references, 39 jurisdiction-wide surveys were identified. Of those, 22 surveys used sufficiently similar research methods to allow further statistical analysis and comparisons (Appendix 2). Response rates ranged from 40.0 to $84.0 \%$ (median: $65.9 \%)$. The 22 included surveys adopted or modified questionnaires that were developed in the Netherlands in the early 1990s [24] and used similar definitions of end-of-life practices, survey methods, and statistical analysis. Two main sampling strategies were used to identify responding physicians: random sampling of death certificates, and the use of physician registries. In these surveys, physicians were either interviewed individually or responded to selfadministered questionnaires.

Figures 2, 3, 4, 5, 6 and 7 present end-of-life practice frequencies by year. The original studies did not allow to fully distinguishing end-of-life practices according to their legal status, as per our descriptive classification (Table 1). For example, original studies did not distinguish treatment withdrawal with or without voluntary patient request. Also, the use of opiates and sedatives did not distinguish whether these drugs were adjusted to symptom management or used with the intention to cause death.

Treatment withholding/withdrawal and the use of drugs for symptom management were the most frequent end-of-life practices. The intentional use of lethal drugs was less frequent, with frequency consistently below $5 \%$ of all deaths.

The total predicted percentages of death in which physicians reported having made an end-of-life decision increased from 38.0 to $64.9 \%$ between 1990 and 2010. Significant changes were found in the frequency of all end-of-life practices over time $(p<0.001$ for all). The magnitude of change in the predicted frequencies of end-of-life practices was greater for the use of opioids $(+15.27 \%$ in annual practice frequency between 1990 to 2010) and for the use of sedatives with possible life-shortening effects $(+6.78 \%)$. Changes in frequencies were smaller for treatment withholding or withdrawal $(-0.73 \%)$, and for the intentional use of lethal drugs self-administered by patients $(-0.17 \%)$, administered by professionals with patient request $(+0.71 \%)$, or administered by professionals without patient request $(-0.65 \%)$. Changes in opioid use were significantly correlated with changes in: the use of sedatives, in the intentional use of lethal drugs administered by patients, and in the intentional use of lethal drugs without patient request $(p<0.05)$. Time trends estimated from Dutch or Belgian data showed the same directions of change as those predicted from all jurisdictions, except for withholding or withdrawal of treatment $(p<0.001)$.

\section{Discussion}

Key findings

To the best of our knowledge, this is the first systematic review to take a comprehensive look at international variations in end-of-life practices over time from 1990 to 2010. This review showed an increase in the frequency of cases where physicians reported having made a decision that may have influenced the timing of death, which is consistent with previous findings [11]. A unique contribution of this review is its documentation of a significant increase in the use 


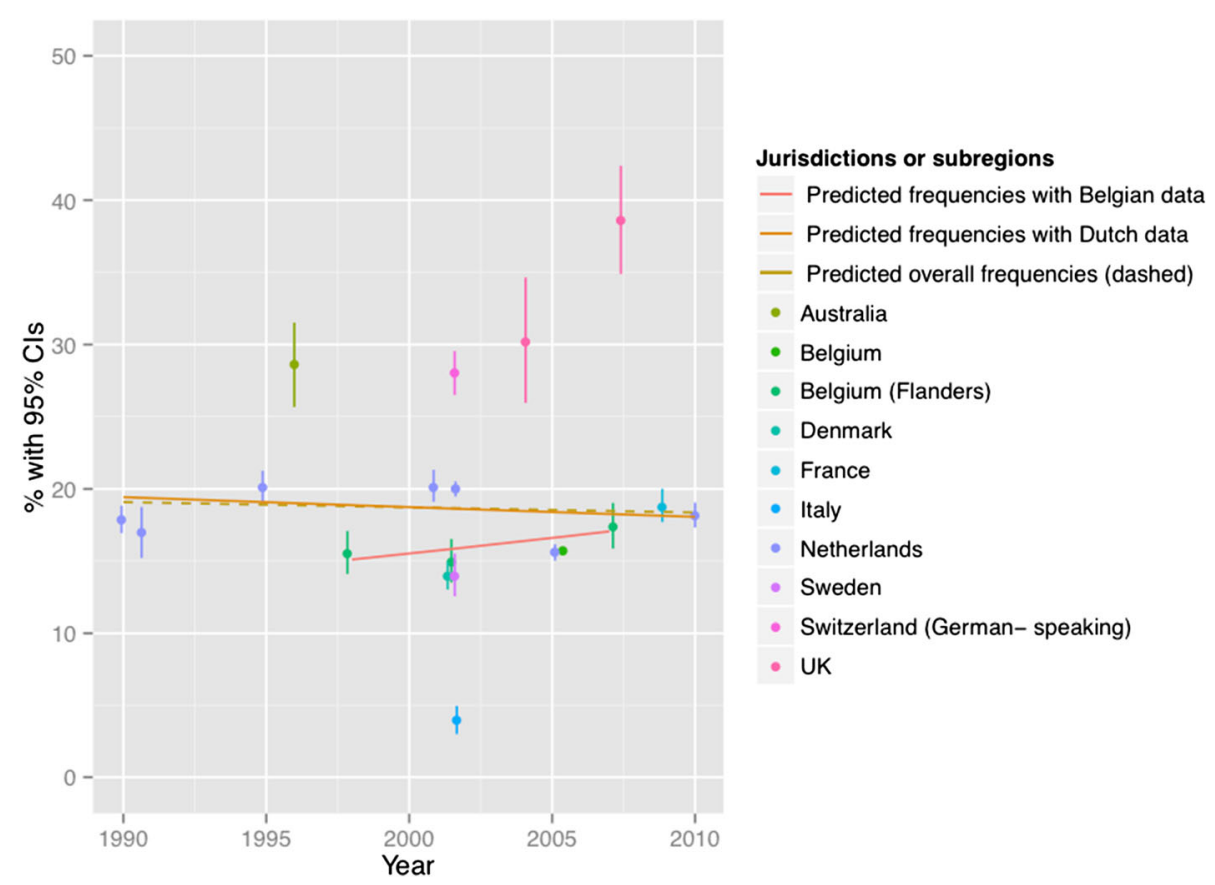

Fig. 2 Withholding or withdrawal of treatment with the potential to prolong life. Note: $\mathrm{Cl}=$ confidence interval; United Kingdom = UK. $X^{2}=36833$ (null hypothesis: all frequencies the same); $p<0.001$. The coefficient of year $=-0.002, p<0.001$ among all surveys; greater than zero suggesting positive changes from 1990 to 2010, lower suggesting the opposite. The coefficient of year $=-0.0045, p<0.001$ among Dutch surveys only. The coefficient of year $=0.0161, p<0.001$ among Belgian surveys only. See Appendix 3 for regression coefficients

of opiates and sedatives over time, as opposed to other end-of-life practices.

The way opiate and sedative use is categorized in the original studies makes it difficult to interpret these time trends, because study questionnaires do not clearly distinguish the use of opiates and sedatives with or without the intention to hasten death [24]. For example, practices labeled in original studies as "intensification of symptom alleviation" include the use of drugs with a partial intention to hasten death [25-27]. Accordingly, the observed increase in the use of opiates and sedatives could mean that physicians are becoming more prone to use these drugs for symptom management. It may also reflect increasingly using opiates and sedatives with the intention of hastening patients' death among physicians. The observation that the use of opiates with possible lifeshortening effects is negatively correlated with the intentional use of lethal drugs could support the hypothesis of a "substitution effect" between different end-of-life practices. This suggests that drugs clearly associated with an intention to hasten death (e.g. neuromuscular blockers) are being replaced by opiates and sedatives in situations where the use of lethal drug is more difficult to justify in legal terms. Alternatively, these trends could simply reflect more professional willingness and patients' expectations to treat pain and symptoms at the end-of-life. Use of these drugs could have become more strongly embedded in clinical and social practices as more information becomes available about the beneficial use of opiates and sedatives for symptom management [28].

\section{Policy and research implications}

This review highlights the importance of exploring the potential effects of public policies on all end-oflife practices, rather than focusing exclusively on those targeted in policy documents. For example, a number of studies have explored the relationship between "euthanasia" legalization in the Netherlands and Belgium and the use of lethal drugs with the explicit intention to hasten death $[29,30]$. However, the review shows that the magnitude of predicted changes in intentional use of lethal drugs is much less than the use of opioids or sedatives with possible life-shortening effects. Focusing on small changes in the frequencies of intentional use of 


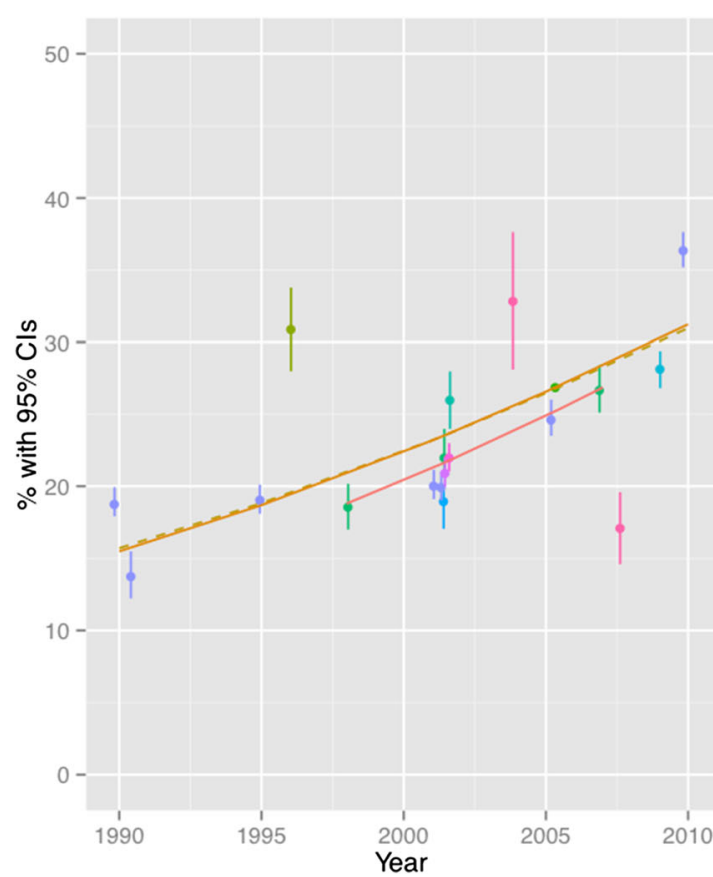

\section{Jurisdictions or subregions}

- Predicted frequencies with Belgian data

- Predicted frequencies with Dutch data

- Predicted overall frequencies (dashed)

- Australia

- Belgium

- Belgium (Flanders)

- Denmark

- France

- Italy

- Netherlands

- Sweden

- Switzerland (German- speaking)

- UK

Fig. 3 Use of opiates with possible life-shortening effects. Note: See Fig. 2 for abbreviations. $X^{2}=37199$ (null hypothesis: all frequencies the same), $p<0.001$. Thecoefficient of year $=0.0440, p<0.001$ among all surveys; greater than zero suggesting positive changes from 1990 to 2010, lower suggesting the opposite). The coefficient of year $=0.0454, p<0.001$ among Dutch surveys. The coefficient of year $=0.0513, p<0.001$ among Belgian surveys. See Appendix 3 for regression coefficients

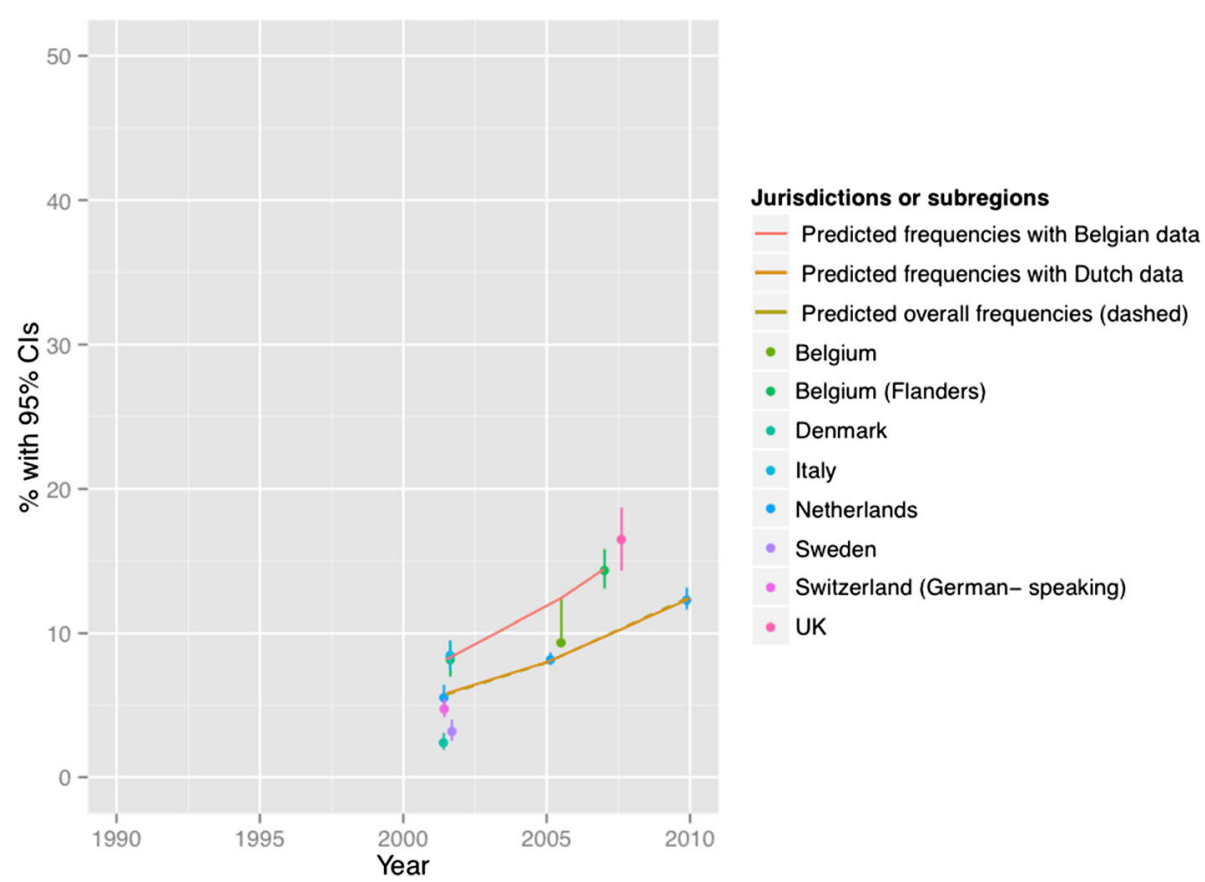

Fig. 4 Use of sedatives with possible life-shortening effects. Note: See Fig. 2 for abbreviations. $X^{2}=19410$ (null hypothesis: all frequencies the same), $p<0.001$. The coefficient of year $=0.1006, p<0.001$ among all surveys; greater than zero suggesting positive changes from 1990 to 2010 , lower suggesting the opposite. The coefficient of year $=0.0974, p<0.001$ among Dutch surveys. The coefficient of year $=0.1162, p<0.001$ among Belgian surveys. See Appendix 3 for regression coefficients 


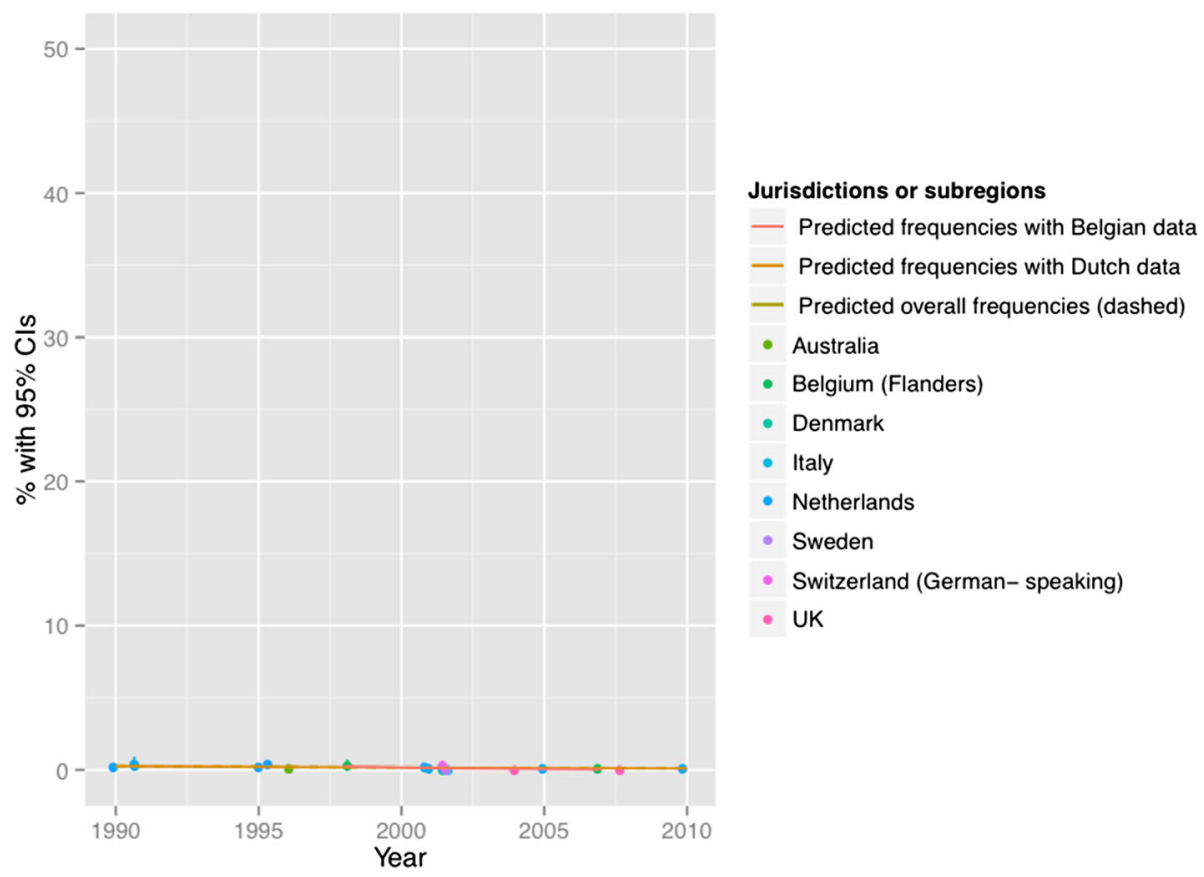

Fig. 5 Intentional use of lethal drugs self-administered by patients. Note: See Fig. 2 for abbreviations. $X^{2}=1716$ (null hypothesis: all freqiuencies the same), $p<0.001$. The coefficient of year $=-0.0492, p<0.001$ among all surveys; greater than zero suggesting positive changes from 1990 to 2010, lower suggesting the opposite. The coefficient of year $=-0.0442, p<0.001$ among Dutch surveys. The coefficient of year $=-0.2291$, $p<0.001$ among Belgian surveys. See Appendix 3 for regression coefficients

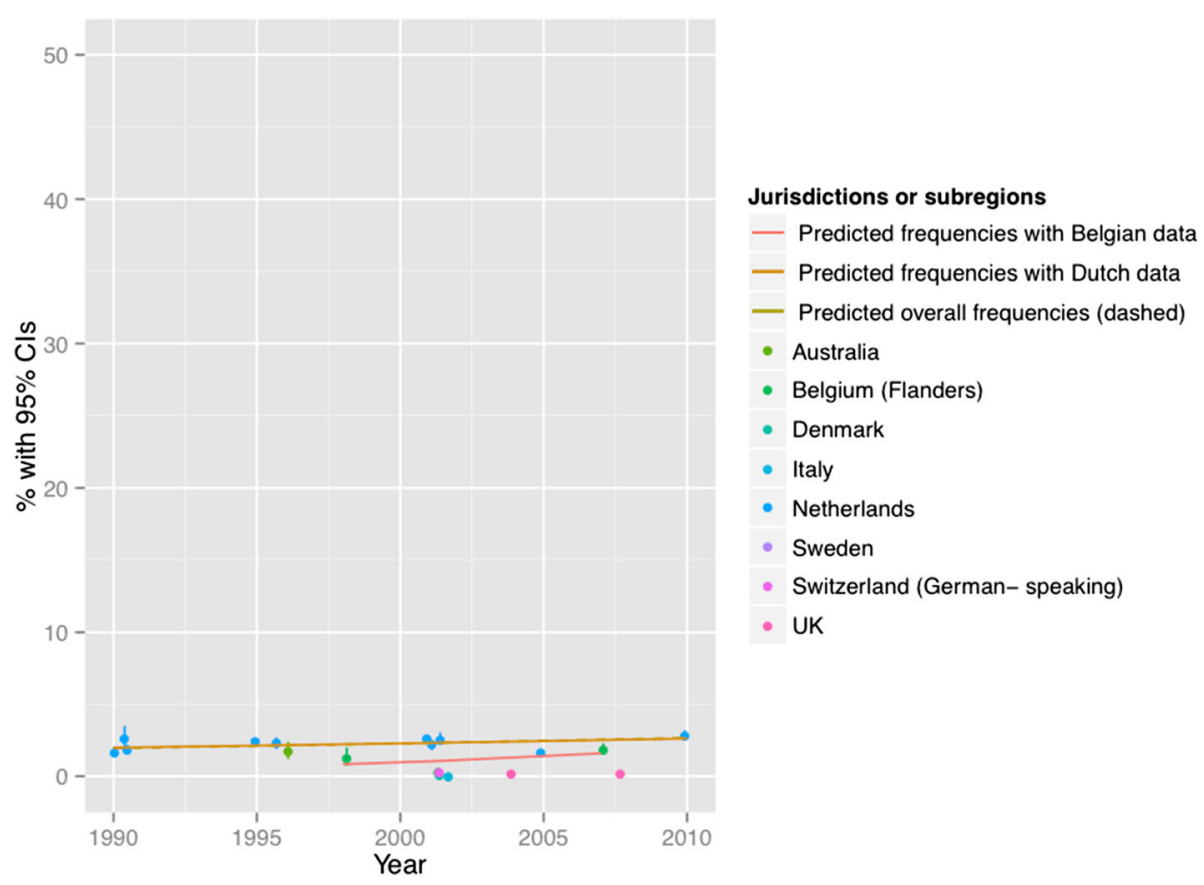

Fig. 6 Intentional use of lethal drugs administered by professionals with patient request. Note: See Fig. 2 for abbreviations. $X^{2}=8678$ (null hypothesis: all frequencies the same), $p<0.001$ (simulated). The coefficient of year $=0.0159, p<0.001$ among all surveys; greater than zero suggesting positive changes from 1990 to 2010, lower suggesting the opposite). The coefficient of year $=0.0142, p<0.001$ among Dutch surveys. The coefficient of year $=0.0730, p<0.001$ among Belgian surveys. See Appendix 3 for regression coefficients 


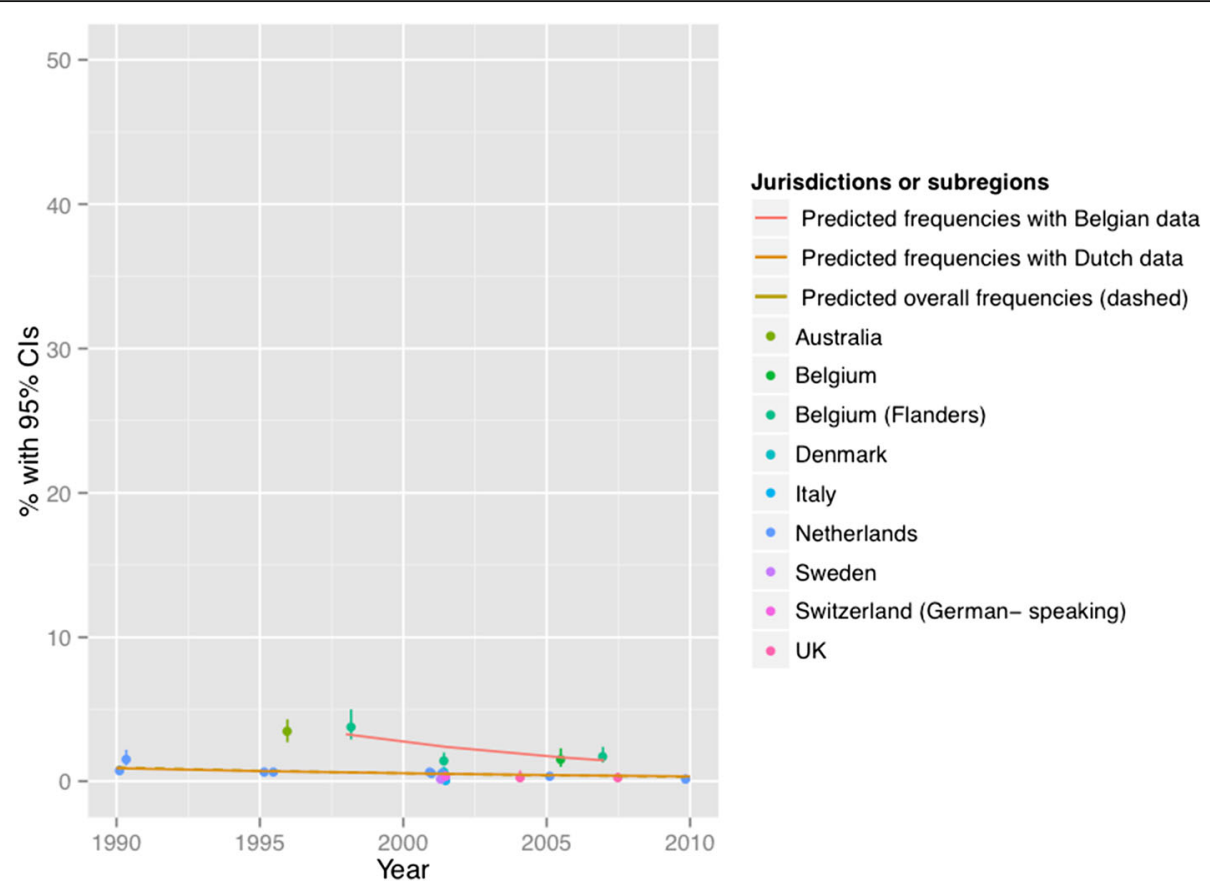

Fig. 7 Intentional use of lethal drugs administered by professionals without patient request. Note: See Fig. 2 for abbreviations. $X^{2}=17372$ (null hypothesis: all frequencies the same), $p<0.001$ (simulated). The coefficient of year $=-0.0574, p<0.001$ among all surveys; greater than zero suggesting positive changes from 1990 to 2010, lower suggesting the opposite). The coefficient of year $=-0.0496, p<0.001$ among Dutch surveys. The coefficient of year $=-0.0924, p<0.001$ among Belgian surveys. See Appendix 3 for regression coefficients

lethal drugs risks overlooking the greater potential impact on the use of opiates and sedatives in endof-life care.

This review also highlights the need for better articulation between end-of-life research and policy. The current confusion in empirical research between the use of opiates and sedatives with or without the intention to hasten death makes it difficult to interpret changing patterns in the use of these drugs because practices with different legal status are grouped together [6]. Better alignment between end-of-life practice classification in policy documents and empirical research would facilitate testing of policy-relevant hypotheses about the potential impacts of different policies on end-of-life practices. Our findings also underscore the importance of international research collaborations to harmonize study methods. Such collaborations have emerged in Europe (e.g. the EURELD consortium [31]), but are less developed in North America and elsewhere, which limits the potential for international comparisons.

\section{Strengths and limitations}

A strength of this review is the exhaustive efforts made to synthesize international evidence on a range of end-of-life practices. This approach offers a complementary perspective to previous reviews that focused on a single practice or a specific jurisdiction $[7,10,29,32]$. The use of a descriptive classification of end-of-life practices is a novel approach to systematically review evidence on end-of-life practice, and helped deal with international variations in labeling and definitions. This descriptive classification also clarifies areas of potential confusion when practices with different legal status were grouped together in original studies. Variations due to sampling and weighting procedures were also taken into account in the statistical analysis of end-of-life practice frequency. This is an improvement upon previous reviews that did not conduct statistical tests at all, or neglected the sampling variability of reported frequencies [7].

There are several limitations in this review. We only search for studies published in English and French. The increase in opioid use may result from both the intent to manage symptoms and to hasten death and we do not have evidence to assess this relationship. We found that comparative international evidence is limited by differences in study methods, end-of-life practice definitions, data collection 
Table 1 Relationship between systematic review classification and original studies

\begin{tabular}{|c|c|c|}
\hline $\begin{array}{l}\text { Figure } \\
\text { number }\end{array}$ & Systematic review classification & Example of labelling and definitions used in original study \\
\hline 2 & $\begin{array}{l}\text { Witholding or withdrawal of treatment with the } \\
\text { potential to prolong life }\end{array}$ & $\begin{array}{l}\text { "Non-treatment decisions »: the withholding or withdrawal of treatment in } \\
\text { situations where the treatment would probably have prolonged life [24]; withhold } \\
\text { or withdraw medical treatment while taking into account the possibility or certainty } \\
\text { that this would hasten the patient's death or with the explicit intention of hastening } \\
\text { the patient's death [31]; withheld or withdrawn medical treatment while taking into } \\
\text { account the possible hastening of death (only for cases in which there was no single } \\
\text { most explicit intention, the administration of drugs prevailed over the withholding } \\
\text { or withdrawing of treatment) [36]. Note: Inconsistently report whether drugs were } \\
\text { administered with or without patient voluntary request. }\end{array}$ \\
\hline
\end{tabular}

$3 \quad$ Use of opiates with possible life-shortening effects

«Alleviation of pain and symptoms » : alleviation of pain and symptoms with opioids in such dosages that the patient's life might have been shortened [24]; intensify the alleviation of pain and suffering while taking into account the possibility or certainty that this would hasten the patient's death or partly with the intention of hastening the patient's death [31]. Note: includes cases where opioids were used with the intention to hasten death. Inconsistently report whether drugs were administered with or without patient voluntary request.

$4 \quad$ Use of sedatives with possible life-shortening effects

"Continuous deep sedation »: deeply and continuously sedated until death [36]; the patient receive drugs, such as barbiturates or benzodiazepines, to keep him/her continuously in deep sedation or coma until death [26]. Note: does not distinguish whether sedatives were used with or without the intention to hasten death. Inconsistently report whether drugs were administered with or without patient voluntary request.

$5 \quad$ Intentional use of lethal drugs self-administered by patients

"Assisted suicide »: the prescription or supply of drugs by a physician with the explicit intention of shortening life, when the drug is administered by patients $[24,31]$. Note: does not include the use of drugs with the "partial » intention to cause death.

$6 \quad$ Intentional use of lethal drugs administered by

«Euthanasia »: the prescription, supply or administration of drugs with the explicit intention of shortening life, when the dru gis administered by professionals [24]; death as the result of the administration, supply, or prescription of drugs with the explicit intention of hastening the patient's death (administered by professionals) [31]. Note: does not include the use of drugs with the «partial » intention to cause death.

$7 \quad$ Intentional use of lethal drugs administered by «Termination of life without a patient request »: the prescription, supply or administration of drugs with the explicit intention of shortening life (without patient explicit request) [24]; death as the result of the administration, supply, or prescription of drugs with the explicit intention of hastening the patient's death (without patient explicit request) [31]. Note: does not include the use of drugs with the « partial » intention to cause death.

approaches, sampling strategies, response rates, and target patient and professional groups. A limited number of surveys used similar methods allowing comparisons across jurisdictions and over time. Nonetheless, some degree of heterogeneity remains in the included surveys. For example, the two United Kingdom studies included surveyed different physician groups and used different versions of the same questionnaire [33, 34]. Other European surveys also excluded children under one years old [31] or drew their sample from a specific region (e.g. Flanders in Belgium) [35]. As a result, some of the observed international variations may still reflect differences in study methods rather than actual differences in practice frequency. Also, only a limited number of European jurisdictions have conducted repeated surveys over time. Accordingly, regression models are largely driven by data from the Netherlands and Belgium, and observed time trends may be less generalizable to other jurisdictions. The lack of studies in other jurisdictions, such as the United States and Canada may also limit the generalizability of ther results.

\section{Conclusions}

The use of opiates and sedatives with possible lifeshortening effects appears to have significantly increased over time from 1990 to 2010. Treatment withholding/ withdrawal and the use of drugs for symptom management are the most frequent end-of-life practices. The intentional use of lethal drugs is less frequent, with frequency consistently below $5 \%$ of all deaths. Better distinction between practices with different legal status is required to properly interpret the policy significance of these changes. Research on the effects of public policies should take a comprehensive look at changing the end-of-life practice patterns, rather than focus on a limited range of practices. 
Appendix 1

Table 2 The search terms for each academic database

\begin{tabular}{|c|c|c|c|c|c|c|c|c|c|}
\hline & PubMed & Embase & Psyclnfo & $\begin{array}{l}\text { Web of Science } \\
\text { (SCl, SSCI) }\end{array}$ & CINAHL & $\begin{array}{l}\text { International } \\
\text { Bibliography of } \\
\text { the Social } \\
\text { Sciences }\end{array}$ & $\begin{array}{l}\text { Sociological } \\
\text { abstracts }\end{array}$ & PAIS International & $\begin{array}{l}\text { Worldwide Political } \\
\text { Science Abstracts }\end{array}$ \\
\hline Euthanasia & $\begin{array}{l}\text { Euthanasia[MAJR:NOEXP] } \\
\text { OR Euthanasia, } \\
\text { active[MAJR:NOEXP] OR } \\
\text { Euthanasia, Active, } \\
\text { Voluntary[MAR] OR } \\
\text { Suicide, assisted[MAR] } \\
\text { OR Deep sedation[MAR] } \\
\text { OR Euthanasia*[T] OR } \\
\text { Assisted suicide**T] OR } \\
\text { Assisted death*[T] OR } \\
\text { Assisted dying[TI] OR } \\
\text { "Aid in dying" [TI] OR } \\
\text { "Termination of life"[TI] } \\
\text { OR Shorten life[TI] or } \\
\text { Shortens life[T]] or Life } \\
\text { Shorten*[T]] or Mercy } \\
\text { killing[T]] OR ("End of } \\
\text { life"[TI] AND (Decision*[T]] } \\
\text { OR Practice*[TI]) OR Lethal } \\
\text { drug*[T]] OR Deep } \\
\text { sedation[TI] OR } \\
\text { Continuous sedation[TI] } \\
\text { OR Terminal sedation[TI] }\end{array}$ & $\begin{array}{l}\text { *Euthanasia/or *Active } \\
\text { euthanasia/or } \\
\text { *Voluntary } \\
\text { euthanasia/OR } \\
\text { *Assisted suicide/OR } \\
\text { *Deep sedation/or } \\
\text { (Euthanasia? OR } \\
\text { (Assisted adj2 } \\
\text { (Suicide? OR Death? } \\
\text { OR Dying)) or "Aid } \\
\text { in dying" OR } \\
\text { ((Termination or } \\
\text { Shorten*) adj2 Life) } \\
\text { or Mercy killing OR } \\
\text { ("End of life" adj2 } \\
\text { (Decision? OR } \\
\text { Practice?)) OR Lethal } \\
\text { drug? OR ((Deep or } \\
\text { Continuous or } \\
\text { Terminal) adj2 } \\
\text { Sedation)).ti }\end{array}$ & $\begin{array}{l}\text { *Euthanasia/or } \\
\text { *Assisted Suicide/or } \\
\text { (Euthanasia? OR } \\
\text { (Assisted adj2 } \\
\text { (Suicide? OR Death? } \\
\text { OR Dying)) or "Aid } \\
\text { in dying" OR } \\
\text { ((Termination or } \\
\text { Shorten*) adj2 Life) } \\
\text { or Mercy killing OR } \\
\text { ("End of life" adj2 } \\
\text { (Decision? OR } \\
\text { Practice?)) OR Lethal } \\
\text { drug? OR ((Deep or } \\
\text { Continuous or } \\
\text { Terminal) adj2 } \\
\text { Sedation)).ti }\end{array}$ & $\begin{array}{l}\text { TT = (Euthanasia* OR } \\
\text { (Assisted NEAR/2 } \\
\text { (Suicide? OR Death? } \\
\text { OR Dying)) OR "Aid } \\
\text { in dying" OR "Mercy } \\
\text { killing" OR (Life } \\
\text { NEAR/2 (Shorten* } \\
\text { or Termination)) } \\
\text { OR ("End of life" } \\
\text { NEAR/2 (Decision? } \\
\text { OR Practice?)) OR } \\
\text { "Lethal drug*" OR } \\
\text { (Sedation NEAR/2 } \\
\text { (Deep OR } \\
\text { Continuous } \\
\text { OR Terminal))) }\end{array}$ & $\begin{array}{l}\text { MM "Euthanasia" } \\
\text { OR MM "Suicide, } \\
\text { Assisted" OR TI } \\
\text { (Euthanasia* } \\
\text { OR (Assisted N2 } \\
\text { (Suicide? OR Death? } \\
\text { OR Dying)) OR "Aid } \\
\text { in dying" OR "Mercy } \\
\text { killing" OR (Life N2 } \\
\text { (Shorten* or } \\
\text { Termination)) OR } \\
\text { ("End of life" N2 } \\
\text { (Decision? OR } \\
\text { Practice?)) OR } \\
\text { "Lethal drug*" OR } \\
\text { (Sedation N2 (Deep } \\
\text { OR Continuous } \\
\text { OR Terminal))) }\end{array}$ & \multirow[t]{3}{*}{$\begin{array}{l}\text { TI,SU(Euthanasia* } \\
\text { OR (Assisted } \\
\text { NEAR/2 (Suicide* } \\
\text { OR Death* OR } \\
\text { Dying)) OR "Aid } \\
\text { in dying" OR } \\
\text { "Mercy killing" } \\
\text { OR (Life NEAR/2 } \\
\text { (Shorten* or } \\
\text { Termination)) OR } \\
\text { ("End of life" } \\
\text { NEAR/2 (Decision* } \\
\text { OR Practice*)) OR } \\
\text { "Lethal drug*" } \\
\text { OR (Sedation } \\
\text { NEAR/2 (Deep OR } \\
\text { Continuous OR } \\
\text { Terminal))) }\end{array}$} & \multirow[t]{3}{*}{$\begin{array}{l}\text { TI,SU(Euthanasia* } \\
\text { OR (Assisted } \\
\text { NEAR/2 (Suicide* } \\
\text { OR Death* OR } \\
\text { Dying)) OR "Aid } \\
\text { in dying" OR } \\
\text { "Mercy killing" } \\
\text { OR (Life NEAR/2 } \\
\text { (Shorten* or } \\
\text { Termination)) } \\
\text { OR ("End of life" } \\
\text { NEAR/2 (Decision* } \\
\text { OR Practice*)) OR } \\
\text { "Lethal drug*" } \\
\text { OR (Sedation } \\
\text { NEAR/2 (Deep OR } \\
\text { Continuous OR } \\
\text { Terminal))) }\end{array}$} & \multirow[t]{3}{*}{$\begin{array}{l}\text { TI,AB,SU(Euthanasia* } \\
\text { OR (Assisted NEAR/2 } \\
\text { (Suicide* OR Death* } \\
\text { OR Dying)) OR "Aid } \\
\text { in dying" OR "Mercy } \\
\text { killing" OR (Life } \\
\text { NEAR/2 (Shorten* } \\
\text { or Termination)) OR } \\
\text { ("End of life" NEAR/2 } \\
\text { (Decision* OR } \\
\text { Practice*)) OR } \\
\text { "Lethal drug*" OR } \\
\text { (Sedation NEAR/2 } \\
\text { (Deep OR } \\
\text { Continuous OR } \\
\text { Terminal))) }\end{array}$} & \multirow[t]{3}{*}{$\begin{array}{l}\text { TI,AB,SU(Euthanasia* } \\
\text { OR (Assisted NEAR/2 } \\
\text { (Suicide* OR Death** } \\
\text { OR Dying)) OR "Aid } \\
\text { in dying" OR "Mercy } \\
\text { killing" OR (Life } \\
\text { NEAR/2 (Shorten* or } \\
\text { Termination)) OR } \\
\text { ("End of life" NEAR/2 } \\
\text { (Decision* OR } \\
\text { Practice*)) OR } \\
\text { "Lethal drug*" OR } \\
\text { (Sedation NEAR/2 } \\
\text { (Deep OR } \\
\text { Continuous OR } \\
\text { Terminal))) }\end{array}$} \\
\hline $\begin{array}{l}\text { Systematic } \\
\text { review }\end{array}$ & $\begin{array}{l}\text { Meta-analysis[PT] or } \\
\text { ((Review[PT] or } \\
\text { Review[TI]) AND } \\
\text { (PubMed[TIAB] or } \\
\text { Medline[TIAB] or } \\
\text { Embase[TIAB] or } \\
\text { CINAHL[TIAB] or } \\
\text { Psyclnfo[TIAB])) or } \\
\text { Cochrane Database } \\
\text { Syst Rev[TA] or Meta- } \\
\text { Analysis[TI] or Meta } \\
\text { analys*[TI] or } \\
\text { Systematic[TI] }\end{array}$ & $\begin{array}{l}\text { Meta analysis/ } \\
\text { OR Systematic } \\
\text { review/or (Review/or } \\
\text { Review.ti) AND } \\
\text { (PubMed or Medline } \\
\text { or Embase or CINAHL } \\
\text { or Psyclnfo).ab) or } \\
\text { Cochrane.jw or } \\
\text { (Meta-Analysis or } \\
\text { Metaanalys* or } \\
\text { Systematic).ti }\end{array}$ & $\begin{array}{l}\text { (Meta analysis or } \\
\text { Systematic } \\
\text { review).id,md or } \\
\text { ((Literature review/ } \\
\text { or Literature } \\
\text { Review.id,md or } \\
\text { Review.ti) AND } \\
\text { (PubMed or Medline } \\
\text { or Embase or } \\
\text { CINAHL).ab) or } \\
\text { Cochrane.jw or } \\
\text { (Meta-Analysis or } \\
\text { Metaanalys* or } \\
\text { Systematic).ti }\end{array}$ & $\begin{array}{l}\text { TS }=(\text { PubMed } \\
\text { or Medline or } \\
\text { Embase or CINAHL } \\
\text { or Psyclnfo) AND } \\
\text { DOCUMENT TYPES: } \\
\text { (Review) OR TI = } \\
\text { ("Meta Analysis" OR } \\
\text { Systematic OR } \\
\text { Metaanalys*) }\end{array}$ & $\begin{array}{l}\text { MH "Meta-Analysis" } \\
\text { or MH "Systematic } \\
\text { review" OR PT } \\
\text { Systematic review } \\
\text { or ((PT Review or } \\
\text { TI Review) AND } \\
\text { AB (PubMed or } \\
\text { Medline or Embase } \\
\text { or CINAHL or } \\
\text { Psyclnfo)) or JT } \\
\text { Cochrane or TI } \\
\text { (Meta-Analysis or } \\
\text { Metaanalys* or } \\
\text { Systematic) }\end{array}$ & & & & \\
\hline $\begin{array}{l}\text { Empirical } \\
\text { studies }\end{array}$ & $\begin{array}{l}\text { Comparative study[PT] } \\
\text { or Observational } \\
\text { Study[PT] OR Cohort } \\
\text { studies[MH] OR Cross- } \\
\text { Sectional Studies[MH] } \\
\text { OR Cross Cultural } \\
\text { Comparison[MH] or } \\
\text { Anthropology, }\end{array}$ & $\begin{array}{l}\text { Comparative study/or } \\
\text { Observational study/ } \\
\text { or Cohort analysis/or } \\
\text { Longitudinal study/or } \\
\text { Prospective study/OR } \\
\text { Retrospective study/ } \\
\text { or Cross-sectional } \\
\text { study/or Cultural }\end{array}$ & $\begin{array}{l}\text { (Empirical study } \\
\text { or Focus group } \\
\text { or Followup study } \\
\text { or Interview or } \\
\text { Longitudinal study } \\
\text { or Prospective study } \\
\text { or Qualitative study } \\
\text { or Quantitative }\end{array}$ & $\begin{array}{l}\text { TS = ("Before and } \\
\text { after" OR Cohort OR } \\
\text { "Cross sectional" OR } \\
\text { "Cultural } \\
\text { anthropolog*" } \\
\text { OR Empirical OR } \\
\text { Ethnograph* OR } \\
\text { "Focus group?" OR }\end{array}$ & $\begin{array}{l}\text { MH "Comparative } \\
\text { studies" OR MH } \\
\text { "Cross Sectional } \\
\text { Studies" OR MH } \\
\text { "Prospective studies } \\
+ \text { + OR MH } \\
\text { "Retrospective } \\
\text { design" OR MH }\end{array}$ & & & & \\
\hline
\end{tabular}


Table 2 The search terms for each academic database (Continued)

\begin{tabular}{|c|c|c|c|c|}
\hline 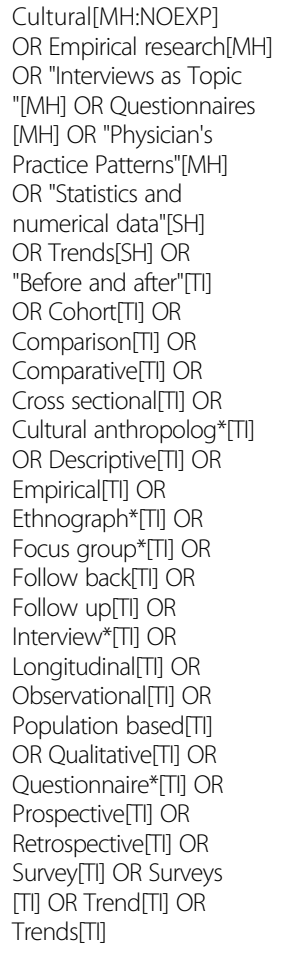 & $\begin{array}{l}\text { anthropology/or } \\
\text { Ethnography/or } \\
\text { Empirical Research/ } \\
\text { or Exp Interview/or } \\
\text { Qualitative research/ } \\
\text { or Exp Questionnaire/ } \\
\text { or Clinical practice/or } \\
\text { Trend study/or } \\
\text { ("Before and after" } \\
\text { OR Cohort OR } \\
\text { Comparison OR } \\
\text { Comparative OR } \\
\text { Cross sectional OR } \\
\text { Cultural anthropolog* } \\
\text { OR Descriptive OR } \\
\text { Empirical OR } \\
\text { Ethnograph* OR } \\
\text { Focus group? OR } \\
\text { Follow back OR } \\
\text { Follow up OR } \\
\text { Interview? OR } \\
\text { Longitudinal OR } \\
\text { Observational OR } \\
\text { Population based OR } \\
\text { Qualitative OR } \\
\text { Questionnaire? OR } \\
\text { Prospective OR } \\
\text { Retrospective OR } \\
\text { Survey? OR Trend?).ti }\end{array}$ & $\begin{array}{l}\text { study or } \\
\text { Retrospective } \\
\text { study).md or Cross } \\
\text { Cultural Differences/ } \\
\text { or "Culture } \\
\text { (Anthropological)"/ } \\
\text { or Ethnography/or } \\
\text { Questionnaires/or } \\
\text { Exp Surveys/or } \\
\text { Clinical practice/or } \\
\text { Trends/ }\end{array}$ & $\begin{array}{l}\text { "Follow back" OR } \\
\text { "Follow up" OR } \\
\text { Interview? OR } \\
\text { Longitudinal OR } \\
\text { Observational OR } \\
\text { "Population based" } \\
\text { OR Qualitative OR } \\
\text { Questionnaire? OR } \\
\text { Prospective OR } \\
\text { Retrospective OR } \\
\text { Survey? OR Trend?) } \\
\text { or TI = (Comparison } \\
\text { OR Comparative OR } \\
\text { Descriptive) }\end{array}$ & $\begin{array}{l}\text { "Questionnaires + " } \\
\text { OR MH "Empirical } \\
\text { Research" OR MH } \\
\text { "Qualitative Studies } \\
\text { + " OR MH "Focus } \\
\text { groups" or MH } \\
\text { Intenviews + OR MH } \\
\text { "Quantitative Studies" } \\
\text { OR MH "Quasi- } \\
\text { Experimental Studies } \\
\text { + " OR TI ("Before } \\
\text { and after" OR Cohort } \\
\text { OR Comparison OR } \\
\text { Comparative OR } \\
\text { Cross sectional OR } \\
\text { Cultural } \\
\text { anthropolog* OR } \\
\text { Descriptive OR } \\
\text { Empirical OR } \\
\text { Ethnograph* OR } \\
\text { Focus group? OR } \\
\text { Follow back OR } \\
\text { Follow up OR } \\
\text { Interview? OR } \\
\text { Longitudinal OR } \\
\text { Observational OR } \\
\text { Population based OR } \\
\text { Qualitative OR } \\
\text { Questionnaire? OR } \\
\text { Prospective OR } \\
\text { Retrospective OR } \\
\text { Sunvey? OR Trend?) }\end{array}$ \\
\hline
\end{tabular}




\section{Appendix 2}

Table 3 Variations in study methods for 39 jurisdiction-wide surveys and 22 included in analysis of practice variation

\begin{tabular}{|c|c|c|c|c|c|}
\hline \multirow[t]{2}{*}{ Surveys [1] } & \multirow{2}{*}{$\begin{array}{l}\text { Included } \\
\text { for practice } \\
\text { variation } \\
\text { analysis }\end{array}$} & \multirow{2}{*}{$\begin{array}{l}\text { Reasons for } \\
\text { exclusion [2] }\end{array}$} & \multicolumn{3}{|l|}{ Article information [3] } \\
\hline & & & Title & $\begin{array}{l}\text { Year of } \\
\text { publication }\end{array}$ & Authors \\
\hline $\begin{array}{l}\text { Netherlands } \\
\text { 1995a }\end{array}$ & Yes & & $\begin{array}{l}\text { Euthanasia and other end-of-life } \\
\text { decisions in the Netherlands in } \\
\text { 1990,1995, and } 2001\end{array}$ & 2003 & $\begin{array}{l}\text { Onwuteaka-Philipsen, Bregie } \\
\text { D.van der Heide, AgnesKoper, } \\
\text { DirkKeij-Deerenberg, Ingeborg } \\
\text { Rietjens, Judith A.Rurup, Mette } \\
\text { L.Vrakking, Astrid M.Georges, } \\
\text { Jean JacquesMuller, Martien } \\
\text { T.van der Wal, Gerritvan der } \\
\text { Maas, Paul J. }\end{array}$ \\
\hline $\begin{array}{l}\text { Netherlands } \\
\text { 1990a }\end{array}$ & Yes & & $\begin{array}{l}\text { Euthanasia and other medical } \\
\text { decisions concerning the end } \\
\text { of life }\end{array}$ & 1991 & $\begin{array}{l}\text { van der Maas, P. J.Vandelden, } \\
\text { J. J. M.Pijnenborg, L.Looman, } \\
\text { C. W. N. }\end{array}$ \\
\hline
\end{tabular}

Characteristics of professionals surveyed

Characteristics of patients

$\begin{array}{ll}\text { 1) Specialities; 2) to be actively practising } & \text { Exclusion criteria: the cause of } \\ \text { medicine at the time of interview and } & \text { death precluded any kind of end- } \\ \text { had to have done so for the previous } & \text { of-life decision (e.g., a car accident } \\ 2 \text { years in the same specialty and place } & \text { resulting in instant death) }\end{array}$

resulting in instant death)

1) A stratified random sample of 405

physicians was interviewed, including

152 general practitioners, 50 nursing

home physicians, and 203 specialists

(cardiologists, surgeons, and specialists

in internal medicine, chest disease, and

neurology). (Method, section I Interviews

with physicians); 2) 6642 Dutch doctors

who had signed a death certificate for

which medical end-of-life decision were

possible (excluding sudden deaths, such

accidents.) 5197 responded and returned

the questionnaires

1) Specialities; 2) to be actively practising medicine at the time of interview and

Onwuteaka-Philipsen, Bregie D.van der Heide, AgnesKoper, Rietjens, Judith A.Rurup, Mette L.Vrakking, Astrid M.Georges, had to have done so for the previous

For all inhabitants of the

Netherlands the cause of death is reported to the Central Bureau of Statistics (CBS). The name of the patient is not mentioned on the cause-of-death form but that of the reporting physician is. The medical officer in charge of the cause-ofdeath statistics drew a stratified sample of 7000 deaths from Aug to Dec 1, 1990.

Exclusion criteria: the cause of death precluded any kind of end-of-life decision (e.g., a car accident resulting L.Vrakking, Astrid M.Georges, Jean JacquesMuller, Martien Maas, Paul J.

1) A stratified random sample of 405 physicians was interviewed, including 152 general practitioners, 50 nursinghome physicians, and 203 specialists (cardiologists, surgeons, and specialists in internal medicine, chest disease and neurology). (Method, section I Inteniews with physicians): 2) 6642 Dutch doctors who had signed a death certificate for which medicat end of life decision were possible (excluding sudden deaths, such accidents.) 5197 responded and returned the questionnaires (Method: Section II Death certificates)
For all inhabitants of the Netherlands the cause of death is reported to the Central Bureau of Statistics (CBS). The name of the patient is not mentioned on the cause-of-death form but that of the reporting physician is. The medical officer in charge of the causeof-death statistics drew a stratified sample of 7000 deaths from Aug to Dec 1, 1990 
Table 3 Variations in study methods for 39 jurisdiction-wide surveys and 22 included in analysis of practice variation (Continued)

\begin{tabular}{|c|c|c|c|c|c|}
\hline $\begin{array}{l}\text { Netherlands } \\
2010 \text { a }\end{array}$ & Yes & $\begin{array}{l}\text { Trends in end-of-life practices } \\
\text { before and after the enactment } \\
\text { of the euthanasia law in the } \\
\text { Netherlands from } 1990 \text { to 2010: } \\
\text { a repeated cross-sectional survey }\end{array}$ & 2012 & $\begin{array}{l}\text { Onwuteaka-Philipsen, Bregje D. } \\
\text { Brinkman-Stoppelenburg, } \\
\text { AriannePenning, Corinede } \\
\text { Jong-Krul, Gwen J.van Delden, } \\
\text { Johannes J.van der Heide, Agnes }\end{array}$ & $\begin{array}{l}\text { All attending physicians of the sampled } \\
\text { cases in strata two to five (See question } \\
\text { 6) received a questionnaire. }\end{array}$ \\
\hline
\end{tabular}

Belgium
(Flanders)

2001/2002a

Netherlands

$2001 b$

Yes

Denmark

$2001 / 2002 a$ six European countries: Belgium Denmark, Italy, the Netherlands, Sweden and Switzerland. [Dutch] medische besluiten rond het

levenseinde in 6 europes

anden: belgie, denemarken,

anden: belon, land, zweden en zwitserland

Euthanasia and other end-oflife decisions in the Netherlands. in 1990, 1995, and 2001

End-of-life medical decisions in six European countries: Belgium Denmark, Italy, the Netherlands Sweden and Switzerland. [Dutch] sweden and Switzerland. [Dut levenseinde in 6 europese landen: belgie, denemarken, italie, nederland, zweden en zwitserland
Van Der Heide, A.Deliens, L.Faisst, Danish, Italian, and Dutch samples K.Nilstun, T.Norup, M.Paci, E.Van Der Wal, G.Van Der Maas, P. J. included a stratum in which end-of-life decisions were precluded on the basis of information on the death certificate, for which no questionnaires were sent out. For all other sampled cases, the attending doctors were asked if death had arisen suddenly and unexpectedly.

Onwuteaka-Philipsen, Bregie D.van der Heide, AgnesKoper, DirkKeij-Deerenberg, Ingeborg Rietjens, Judith A Rurup, Mette Rietjens, Judith A.Rurup, Mette L.Vrakking, Astrid M.Georges, Jean JacquesMuller, Martien T.van der Wal,

aisst KNilste, A.Deliens, L. Paci, EVan Der Wal, GVan Der Maas, P. J.

Specialities; 2) to be actively practising medicine at the time of intenview and had to have done so for the previous 2 years in the same specialty and place

Danish, Italian, and Dutch samples included a stratum in which end-of-life decisions were precluded on the basis of information on the death certificate, for which no questionnaires were sent out. For all other sampled cases, the attending doctors were asked if death had arisen suddenly and unexpectedly.
1) All deaths that occurred in that period were assigned to one of five strata. When the cause of death clearly precluded end-of-life decisionmaking), cases were assigned to stratum one. These cases were retained in the sample, but no questionnaires were sent out to the physician. Cases were assigned to one of the other strata looking a the likelihood that an end-of-life decision had preceded death: when this decision was unlikely cause of death was allocated to stratum two when this decision was possible to stratum three, and when this decision was more probable (e.g., cancer) to stratum four. Cases were assigned to stratum five when the physician had noted on the death certificate that they had actively ended the life of the patient.

Random samples of death certificates of people aged 1 year or older from death registries to which all deaths are reported. The sampling period varied between 3 and 6 months, but all deaths that we included arose between June 2001, ar 2002

Exclusion criteria: the cause of death precluded any kind of end-of-life decision (e.g., a car accident resulting in instant death)

Random samples of death certificates of people aged 1 year or older from death registries to which all deaths are reported The sampling period varied between 3 and 6 months, but all deaths that we inclunths, but all deaths that we included (a) 2002 
Table 3 Variations in study methods for 39 jurisdiction-wide surveys and 22 included in analysis of practice variation (Continued)

\begin{tabular}{|c|c|c|c|c|c|c|c|}
\hline $\begin{array}{l}\text { Netherlands } \\
\text { 1994-1998 } \\
\text { (ALS patients) }\end{array}$ & No & $\begin{array}{l}\text { Specific } \\
\text { population of } \\
\text { patients }\end{array}$ & $\begin{array}{l}\text { Euthanasia and physician-assisted } \\
\text { suicide in Dutch patients with } \\
\text { amyotrophic lateral sclerosis. } \\
\text { [Dutch] euthanasie en hulp bij } \\
\text { zelfdoding bij patienten met } \\
\text { amyotrofische laterale sclerose } \\
\text { in nederland }\end{array}$ & 2004 & $\begin{array}{l}\text { Veldink, J. H.Wokke, J. H. J.Van } \\
\text { Der Wal, G.De Jong, J. M. B. V. } \\
\text { Van Den Berg, L. H. }\end{array}$ & $\begin{array}{l}\text { The family physicians of } 279 \text { Dutch } \\
\text { patients who fulfilled the criteria for } \\
\text { possible, probable or definite ALS, who } \\
\text { were known in the Utrecht University } \\
\text { Medical Centre or the Academic Medical } \\
\text { Centre in Amsterdam, the Netherlands, } \\
\text { and who had died in the period 1994- } \\
1998 \text { were asked to fill out a validated } \\
\text { questionnaire about the various medical } \\
\text { end-of-life decisions that had been taken } \\
\text { and their possible clinical, care-related } \\
\text { and social determinants. }\end{array}$ & NA \\
\hline $\begin{array}{l}\text { Australia } \\
\text { 1996b }\end{array}$ & Yes & & $\begin{array}{l}\text { End-of-life decisions in Australian } \\
\text { medical practice }\end{array}$ & 1997 & $\begin{array}{l}\text { Kuhse, H.Singer, P.Baume, P. } \\
\text { Clark, M.Rickard, M. }\end{array}$ & $\begin{array}{l}\text { 1. } 3000 \text { doctors taken at random from a } \\
\text { list of } 27000 \text { Australian doctors extracted } \\
\text { from the Australian Medical Masterfile } \\
\text { Database (Australasian Medical } \\
\text { Publishing Company, Sydney), one of } 27 \\
\text { medical disciplines where there would } \\
\text { be the possibility of making a medical } \\
\text { end-of-life decision; } 2 \text { - the } 27 \text { medical } \\
\text { disciplines (also extracted from the } \\
\text { Australian Medical Masterfile Database) } \\
\text { as comparable as possible with the } \\
\text { broader categories of doctors } \\
\text { (cardiology, surgery, internal medicine, } \\
\text { respiratory medicine [pulmonology], } \\
\text { neurology, general practitioners and } \\
\text { nursing home physicians) who were } \\
\text { attendant to } 87 \% \text { of hospital deaths } \\
\text { and nearly all deaths outside hospitals } \\
\text { in the Netherlands; } 3 \text { - The initial } \\
\text { questions on the questionnaire } \\
\text { narrowed the field of respondents to } \\
\text { include the } 1361 \text { doctors who had } \\
\text { attended a death within the last } \\
12 \text { months. }\end{array}$ & NA \\
\hline $\begin{array}{l}\text { Sweden } \\
\text { 2001/2002a }\end{array}$ & Yes & & $\begin{array}{l}\text { End-of-life medical decisions in } \\
\text { six European countries: Belgium, } \\
\text { Denmark, Italy, the Netherlands, } \\
\text { Sweden and Switzerland. [Dutch] } \\
\text { medische besluiten rond het } \\
\text { levenseinde in } 6 \text { europese landen: } \\
\text { belgie, denemarken, italie, } \\
\text { nederland, zweden en zwitserland }\end{array}$ & 2003 & $\begin{array}{l}\text { Van Der Heide, A.Deliens, L. } \\
\text { Faisst, K.Nilstun, T.Norup, M.Paci, } \\
\text { E.Van Der Wal, G.Van Der Maas, } \\
\text { P. J. }\end{array}$ & $\begin{array}{l}\text { Danish, Italian, and Dutch samples } \\
\text { included a stratum in which end- } \\
\text { of-life decisions were precluded } \\
\text { on the basis of information on the } \\
\text { death certificate, for which no } \\
\text { questionnaires were sent out. For } \\
\text { all other sampled cases, the } \\
\text { attending doctors were asked if } \\
\text { death had arisen suddenly and } \\
\text { unexpectedly. }\end{array}$ & $\begin{array}{l}\text { Random samples of death certificates } \\
\text { of people aged } 1 \text { year or older from } \\
\text { death registries to which all deaths } \\
\text { are reported. The sampling period } \\
\text { varied between } 3 \text { and } 6 \text { months, but } \\
\text { all deaths that we included arose } \\
\text { between June } 2001 \text {, and February } \\
2002 \text {. }\end{array}$ \\
\hline
\end{tabular}


Table 3 Variations in study methods for 39 jurisdiction-wide surveys and 22 included in analysis of practice variation (Continued)

\begin{tabular}{lll}
\hline $\begin{array}{l}\text { Netherlands } \\
\text { 2001/2002a }\end{array}$ & Yes & End-of-life medical decisions in \\
& six European countries: Belgium, \\
& Denmark, Italy, the Netherlands, \\
& Sweden and Switzerland. \\
& [Dutch] medische besluiten \\
& rond het levenseinde in 6 \\
& europese landen: belgie, \\
& denemarken, italie, nederland, \\
& zweden en zwitserland \\
& & End-of-life medical decisions \\
in six European countries: & Belgium, Denmark, Italy, the \\
Switzerland & Yes & Netherlands, Sweden and \\
(German- & & Switzerland. [Dutch] medische \\
speaking) & besluiten rond het levenseinde \\
2001/2002a & in 6 europese landen: belgie, \\
& denemarken, italie, nederland, \\
& zweden en zwitserland \\
& & Hastening death in end-of-life
\end{tabular}

UK 2007/2008b Yes Hastening death in end-of-life care: a survey of doctors

Netherlands, Sweden and

Switzerland. [Dutch] medische

besluiten rond het levenseinde

in 6 europese landen: belgie,

denemarken, italie, nederland,

zweden en zwitserland

\begin{tabular}{|c|c|}
\hline 2003 & $\begin{array}{l}\text { Van Der Heide, A.Deliens, L. } \\
\text { Faisst, K.Nilstun, T.Norup, M.Paci, } \\
\text { E.Van Der Wal, G.Van Der Maas, } \\
\text { P. J. }\end{array}$ \\
\hline 2003 & $\begin{array}{l}\text { Van Der Heide, A.Deliens, L.Faisst, } \\
\text { K.Nilstun, T.Norup, M.Paci, E.Van } \\
\text { Der Wal, G.Van Der Maas, P. J. }\end{array}$ \\
\hline
\end{tabular}

Danish, Italian, and Dutch samples

included a stratum in which end-of-

life decisions were precluded on

the basis of information on the

death certificate, for which no

questionnaires were sent out For

all other sampled cases, the attending

doctors were asked if death had arisen

suddenly and unexpectedly.

included a stratum in which end-

of-life decisions were precluded

on the basis of information on the

death certificate, for which no

questionnaires were sent out. For all

other sampled cases, the attending

doctors were asked if death had

arisen suddenly and unexpectedly.

2009 Seale, Clive

1) Binley's database (http://www.binleys.com/) NA

of UK medical practitioners was used

to send questionnaires to 8857 working

UK medical practitioners, comprising

separate random samples of 2829 GPs,

443 neurologists, 836 specialists in care

of the elderly, 462 specialists in palliative

medicine and 4287 in other hospital

specialties in 2007 to 2008; 2) Excluding

specialties such as public health where

doctors do not normally treat people

who die; 3) Neurologists, palliative

medicine and care of the elderly

specialists were over sampled in relation

to their proportions in the medical

population to enable exploration of the

circumstances of elderly people people

receiving specialist palliative care, and

those with multiple sclerosis (MS) and

motor neurone disease (MND).

2003 Van Der Heide, A.Deliens, L.Faisst,

Danish, Italian, and Dutch samples

K.Nilstun, T.Norup, MPaci, EVan

Der Wal, G.Van Der Maas, P. J.

included a stratum in which end-

of-life decisions were precluded

on the basis of information on the

death certificate, for which no

questionnaires were sent out. For all

other sampled cases, the attending

doctors were asked if death had

arisen suddenly and unexpectedly.
Random samples of death certificates of people aged 1 year or older from death registries to which all deaths are reported The sampling period varied between 3 and 6 months, but all deaths that we included arose betwe June 2001, and Febre uary

Random samples of death certificates of people aged 1 year or older from death registries to which al deam death registice the which all deaths varied between 3 and 6 months, but varied between 3 and 6 months, but
all deaths that we included arose between June 2001, and February 2002.

Random samples of death certificates of people aged 1 year or older from death registries to which all deaths are reported. The sampling period varied between 3 and 6 months, but all. deaths that we included arose between June 2001, and February 2002. 
Table 3 Variations in study methods for 39 jurisdiction-wide surveys and 22 included in analysis of practice variation (Continued)

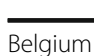

(Flanders)

1998a

Yes

The incidence and characteristics
of end-of-life decisions by GPS

in Belgium

\begin{abstract}
Belgium
2005/2006a
\end{abstract}

Yes

France 2009a

Netherlands

1990 (Prospective)

Yes

Yes

Netherlands

1995b

Belgium

(Flanders)

No

Specific

The first five years of euthanasia

papulation of legislation in Belgium and the

comparison of cases

Euthanasia and other end of life inal three months of life:

nationwide
in Belgium

End-of-life medical decisions in France: a death certificate followup survey 5 years after the 2005

rights and end of life

Euthanasia and other medical decisions concerning the en of life

Euthanasia and other end-of-life decisions in the Netherlands in

1990,1995, and 2001

2004

Bilsen, JohanStichele, Robert

VanderMortier, Freddy

Bernheim, JanDeliens, Luc

Identified the speciality of the

attesting physicians (GP or specialist)

for each of the 3999 sampled death

certificates and selected only the

cases in the data set for which a GP

returned the questionnaire act of parliament on patients' a death certificate in December 2009 405 physicians was interviewed
Van Den Block, L.Deschepper, R.Bilsen, J.Bossuyt, N.Van Casteren, V.Deliens, L.

Pennec, S.Monnier, A. Pontone, S.Aubry, R.

van der Maas, P. J.Vandelden, J. J. M.Pijnenborg, L.Looman, C.W. N.

Onwuteaka-Philipsen, Bregie D.van der Heide, Agneskoper, DirkKeii-Deerenberg Ingeborg Rietjens, Judith A.Rurup, Mette L.Vrakking, Astrid M.Georges, Jean JacquesMuller, Martien T.van der Wal, Gerritvan der Maas, Paul J.

Rurup, Mette L.Smets, Tinne Cohen, JoachimBilsen, Johan Onwuteaka-Philipsen, Bregje D.Deliens, Luc
Inclusion criteria: registered the death of a patient between 1 January 2005 and 31 December 2006 in Belgium

Inclusion criteria: Having completed

1) A stratified random sample of including 152 general practitioners, 50 nursing-home physicians, and 203 specialists (cardiologists, surgeons, and specialists in internal medicine, chest disease, and neurology). (Method, section I Interviews with physicians); 2) 6642 Dutch doctors who had signed a death certificate for which medical end-of-life decision were possible (excluding sudden deaths, such accidents.) 5197 responded and returned the questionnaires

1) Specialities; 2) to be actively practising medicine at the time of interview and had to have done so for the previous 2 years in the same specialty and place

The anonymized databases of the reported cases of euthanasia in Belgium and the Netherlands were made available by the review committees. We selected all cases reported between 22 September 2002 (date of first report in Belgium) and the end of 2007 in both databases
"A $20 \%$ random sample was taken from all death certificates signed between January 1 and April 30, 1998."

Inclusion Criteria: 1) Died between 1 January 2005 and 31 December 2006 in Belgium; 2) Be over the age of one year; 3) Non-sudden death

1) Aged 18 and over; 2) died in France in December 2009

For all inhabitants of the Netherlands the cause of death is reported to the Central Bureau of Statistics (CBS). The name of the patient is not mentioned on the cause-of-death form but that of the reporting physician is. The medical officer in charge of the cause-of-death statistics drew a stratified sample of 7000 deaths from Aug 1 to Dec 1, 1990.

Exclusion criteria : the cause of death precluded any kind of endof-life decision (e.g., a car accident resulting in instant death)

The anonymized databases of the reported cases of euthanasia in Belgium and the Netherlands were made available by the review committees. We selected all committees. We selected all cases 2002 (date of first report in Belgium) 2002 (date of first report in Belgum
and the end of 2007 in both and the en 
Table 3 Variations in study methods for 39 jurisdiction-wide surveys and 22 included in analysis of practice variation (Continued)

\begin{tabular}{|c|c|c|c|c|c|c|c|}
\hline $\begin{array}{l}\text { Netherlands } \\
2005 \text { a }\end{array}$ & Yes & & $\begin{array}{l}\text { End-of-Life Practices in the } \\
\text { Netherlands under the } \\
\text { Euthanasia Act }\end{array}$ & 2007 & $\begin{array}{l}\text { van der Heide, A., B. D. Onwuteaka- } \\
\text { Philipsen, M. L. Rurup, H. M. } \\
\text { Buiting, J. J. van Delden, J. E. } \\
\text { Hanssen-de Wolf, A. G. Janssen, } \\
\text { H. Pasman, J. A. Rietjens, C. J. } \\
\text { Prins, I. M. Deerenberg, J. K. } \\
\text { Gevers, P. J. van der Maas and } \\
\text { G. van der Wal }\end{array}$ & $\begin{array}{l}\text { 1) To be licensed physicians } \\
\text { practicing in Oregon from the } \\
\text { Oregon State Board of Medical } \\
\text { Examiners (BME) in November } \\
\text { 1994; 2) We defined "attending } \\
\text { physicians" as all physicians in } \\
\text { Oregon licensed in the following } \\
\text { specialties: internal medicine, } \\
\text { family practice, general practice, } \\
\text { neurology, gynaecology, } \\
\text { therapeutic radiology, and surgery }\end{array}$ & $\mathrm{NA}$ \\
\hline $\begin{array}{l}\text { Netherlands } \\
2001 c\end{array}$ & No & $\begin{array}{l}\text { Specific } \\
\text { population of } \\
\text { patients }\end{array}$ & $\begin{array}{l}\text { [No conspicuous changes in } \\
\text { the practice of medical end-of- } \\
\text { life decision-making for neonates } \\
\text { and infants in the Netherlands in } \\
2001 \text { as compared to 1995] }\end{array}$ & 2005 & $\begin{array}{l}\text { Vrakking, A. M.van der Heide, } \\
\text { A.Onwuteaka-Philipsen, B. D. } \\
\text { Keij-Deerenberg, I. M.van der } \\
\text { Maas, P. J.van der Wal, G. }\end{array}$ & $\begin{array}{l}\text { The questionnaires which were } \\
\text { sent to the physicians who } \\
\text { reported the deaths, included } \\
\text { structured questions about } \\
\text { whether or not death had been } \\
\text { preceded by end-of-life decisions, } \\
\text { i.e. decisions to withhold or } \\
\text { withdraw potentially life-prolonging } \\
\text { treatment or to administer } \\
\text { (potentially) life-shortening drugs, } \\
\text { and questions about the decision- } \\
\text { making process. }\end{array}$ & $\begin{array}{l}\text { In both years, all deaths of children } \\
\text { under the age of one year that took } \\
\text { place in August-November (1995: } \\
n=338 ; 2001: n=347 \text { ) were studied }\end{array}$ \\
\hline $\begin{array}{l}\text { Netherlands } \\
2005 / 2006 \\
\text { (HGG patients) }\end{array}$ & No & $\begin{array}{l}\text { Specific } \\
\text { population of } \\
\text { patients }\end{array}$ & $\begin{array}{l}\text { Decision-making in the end-of- } \\
\text { life phase of high-grade glioma } \\
\text { patients }\end{array}$ & 2012 & $\begin{array}{l}\text { Sizoo, E. M.Pasman, H. R.Buttolo, } \\
\text { J.Heimans, J. J.Klein, M.Deliens, } \\
\text { L.Reijneveld, J. C.Taphoorn, M. J. }\end{array}$ & $\begin{array}{l}\text { "The physicians involved in end-of- } \\
\text { life care of deceased patients of the } \\
\text { cohort were approached for } \\
\text { participation in the study. (...) If } \\
\text { more than one physician was } \\
\text { involved in end of life care for a } \\
\text { specific patient (for example due to } \\
\text { a transition in health care setting } \\
\text { close before death), all physicians } \\
\text { were approached for participation } \\
\text { in the study" }\end{array}$ & $\begin{array}{l}\text { "adult HGG patients diagnosed in } \\
2005 \text { and } 2006 \text { in three tertiary } \\
\text { referral centres for brain tumour } \\
\text { patients (VU University Medical } \\
\text { Centre and Academic Medical } \\
\text { Centre Amsterdam Amsterdam, } \\
\text { Medical Centre Haaglanden The } \\
\text { Hague, The Netherlands)" }\end{array}$ \\
\hline $\begin{array}{l}\text { Netherlands } \\
1995 \mathrm{c}\end{array}$ & No & $\begin{array}{l}\text { Specific } \\
\text { population of } \\
\text { patients }\end{array}$ & $\begin{array}{l}\text { [No conspicuous changes in } \\
\text { the practice of medical end-of- } \\
\text { life decision-making for neonates } \\
\text { and infants in the Netherlands in } \\
2001 \text { as compared to 1995] }\end{array}$ & 2005 & $\begin{array}{l}\text { Vrakking, A. M.van der Heide, } \\
\text { A.Onwuteaka-Philipsen, B. D. } \\
\text { Keij-Deerenberg, I. M.van der } \\
\text { Maas, P. J.van der Wal, G. }\end{array}$ & $\begin{array}{l}\text { The questionnaires which were sent } \\
\text { to the physicians who reported the } \\
\text { deaths, included structured questions } \\
\text { about whether or not death had } \\
\text { been preceded by end-of-life } \\
\text { decisions, i.e. decisions to withhold } \\
\text { or withdraw potentially life-prolonging } \\
\text { treatment or to administer } \\
\text { (potentially) life-shortening drugs, } \\
\text { and questions about the decision- } \\
\text { making process. }\end{array}$ & $\begin{array}{l}\text { In both years, all deaths of children } \\
\text { under the age of one year that took } \\
\text { place in August-November (1995: } \\
n=338 ; 2001: n=347 \text { ) were studied }\end{array}$ \\
\hline $\begin{array}{l}\text { Belgium } \\
\text { (Hasselt, } \\
\text { Flanders) } \\
\text { 1996a }\end{array}$ & Yes & & $\begin{array}{l}\text { Attitudes, socio-demographic } \\
\text { characteristics, and actual end- } \\
\text { of-life decisions of physicians } \\
\text { in Flanders, Belgium }\end{array}$ & 2003 & $\begin{array}{l}\text { Mortier, F.Bilsen, J.Vander Stichele, } \\
\text { R. H.Bernheim, J.Deliens, L. }\end{array}$ & $\begin{array}{l}\text { "All physicians who signed a death } \\
\text { certificate" in } 1996 \text { in the city of } \\
\text { Hasselt (Flanders) }\end{array}$ & $\begin{array}{l}\text { "All official death certificates of the } \\
970 \text { deaths in Hasselt in } 1996 \text { were } \\
\text { retrieved for the study." }\end{array}$ \\
\hline
\end{tabular}


Table 3 Variations in study methods for 39 jurisdiction-wide surveys and 22 included in analysis of practice variation (Continued)

\begin{tabular}{llllll}
\hline $\begin{array}{l}\text { Belgium } \\
\text { (Flanders) }\end{array}$ & Yes & Trends in medical end-of-life & 2011 & Chambaere, K.Bilsen, J.Cohen, & Every certifying physician was \\
2007a & & $\begin{array}{l}\text { decision making in Flanders, } \\
\text { Belgium 1998-2001-2007 }\end{array}$ & & J.Onwuteaka-Philipsen, B. D. & $\begin{array}{l}\text { sent a 5-page questionnaire for a } \\
\text { maximum of } 5 \text { cases, with at most }\end{array}$ \\
& & & Mortier, F.Deliens, L. & 3 reminders in case of nonresponse,
\end{tabular}

$\begin{array}{llll}\begin{array}{l}\text { Netherlands } \\ 2005 / 2006 \\ \text { (Neonates/infants } \\ \text { (Aug to Nov)) }\end{array} & \begin{array}{l}\text { Specific } \\ \text { population of } \\ \text { patients }\end{array} & \begin{array}{l}\text { Analgesics, sedatives and } \\ \text { neuromuscular blockers as part } \\ \text { of end-of-life decisions in Dutch } \\ \text { NICUs }\end{array} \\ \text { Sweden 1998b No } \quad \text { Specific } & \begin{array}{l}\text { Palliative care, assisted suicide } \\ \text { population } \\ \text { of physicians }\end{array} & \begin{array}{l}\text { and euthanasia: Nationwide } \\ \text { questionnaire to Swedish } \\ \text { physicians }\end{array}\end{array}$

UK 2004b
National survey of end-of-life decisions made by UK medical practitioners neuromuscular blockers as in Dutch NICUs
Verhagen, A. A.Dorscheidt, J. H. C Caring of a infants for newborns Engels, B.Hubben, J. H.Sauer, P. J. in group II (Patients and methods Interviews, p.F435); Group II : stabilised newborns with a poor

$$
\text { prognosis }
$$

Valverius, E.Nilstun, T.Nilsson, B. Inclusion criteria: Swedish Pharmaceutical Statistics OR working in palliative care units in Sweden OR members of the Swedish Association for the Study of Pain

1) A random sample of 1000 general practitioners (GPs) and 1000 hospita specialists listed on Binley's database (www.binleys.com) of all working UK medical practitioners (updated in September 2004) were sent questionnaires, with two follow-up reminders, between October and December 2004: 2) specialties where doctors could not be expected to have attended a death in the previous cevious

Caring of a infants for newborns in group II (Patients and methods Interviews, p.F435); Group II :

stabilised newborns with a poor P. J.

prognosis
We performed a death certificate survey in Flanders, the Flemishspeaking part of Belgium, which has approximately 55,000 deaths per year. This study was similar to those performed in 1998 and 2001. A stratified random sample of deaths was drawn by the central was drawn by the central administration authority for death
certificates, the Flemish Agency for certificates, the Flemish Agency for Care and Health. All deaths between 1 June 2007 and 30 November 2007 of Belgian residents aged to 1 of 4 strata, based on the underlying cause of death as indicated on the death certificate and the estimated corresponding likelihood of an end-of-life practice. Sampling fractions for each stratum increased with this likelihood.

"infants who died before the age of 2 months between October 2005 and September 2006 in the NICUs"

Inclusion criteria: deceased during 1997

"infants who died before the age of 2 months between October 2005 and September 2006 in the NICUs" 
Table 3 Variations in study methods for 39 jurisdiction-wide surveys and 22 included in analysis of practice variation (Continued)

\begin{tabular}{|c|c|c|c|}
\hline $\begin{array}{l}\text { Belgium } \\
\text { (Flanders) } \\
2007 \text { (Death } \\
\text { certificates } \\
\text { (cancer patients)) }\end{array}$ & Yes & & $\begin{array}{l}\text { Trends in End-of-Life Decision } \\
\text { Making in Patients With and } \\
\text { Without Cancer }\end{array}$ \\
\hline $\begin{array}{l}\text { Belgium } \\
\text { (Flanders) } \\
2007 \text { (Death } \\
\text { certificates } \\
\text { (non-cancer } \\
\text { patients)) }\end{array}$ & Yes & & $\begin{array}{l}\text { Trends in End-of-Life Decision } \\
\text { Making in Patients With and } \\
\text { Without Cancer }\end{array}$ \\
\hline $\begin{array}{l}\text { Netherlands } \\
2001 \text { (Children } \\
\text { (1 to 17y) (Aug } \\
\text { to Dec)) }\end{array}$ & No & $\begin{array}{l}\text { Specific } \\
\text { population of } \\
\text { patients }\end{array}$ & $\begin{array}{l}\text { Medical end-of-life decisions for } \\
\text { children in the Netherlands }\end{array}$ \\
\hline $\begin{array}{l}\text { Netherlands } \\
\text { 2005/2006 } \\
\text { (Neonates/ } \\
\text { infants (group II)) }\end{array}$ & No & $\begin{array}{l}\text { Specific } \\
\text { population of } \\
\text { patients }\end{array}$ & $\begin{array}{l}\text { Analgesics, sedatives and } \\
\text { neuromuscular blockers as } \\
\text { part of end-of-life decisions } \\
\text { in Dutch NICUs }\end{array}$ \\
\hline $\begin{array}{l}\text { Netherlands } \\
\text { 1996-1998 } \\
\text { (Dementia in } \\
\text { nursing homes) }\end{array}$ & No & $\begin{array}{l}\text { Specific } \\
\text { population of } \\
\text { patients }\end{array}$ & $\begin{array}{l}\text { End-of-Life Decision Making in } \\
\text { Nursing Home Residents with } \\
\text { Dementia and Pneumonia: } \\
\text { Dutch Physicians' Intentions } \\
\text { Regarding Hastening Death }\end{array}$ \\
\hline
\end{tabular}

$\begin{array}{ll}2013 & \text { Pardon, KoenChambaere, } \\ & \text { KennethPasman, H. Roeline } \\ & \text { W.Deschepper, ReginaldRietjens, } \\ & \text { JudithDeliens, Luc }\end{array}$

Physicians who had attested to the sampled death certificates were sent a 5-page paper-and-pencil

questionnaire by the Flemish Agency about the medical decisions made at the patient's end of life, the decisionmaking process, and the care provided.

2013 Pardon, KoenChambaere, KennethPasman, H. Roeline W. Deschepper, ReginaldRietjens, JudithDeliens, Luc

2005

Vrakking, A. M.van der Heide, A.Arts, W. F.Pieters, R.van der Voort, E.Rietjens, J. A.Onwuteak Philipsen, B. D.van der Maas, P. J.van der Wal, G.

Verhagen, A. A.Dorscheidt, J. H.Engels, B.Hubben, J. H.Sauer, P. J.

van der Steen, Jenny T.van der Wal, GerritMehr, David R.Ooms, Marcel E.Ribbe, Miel W.

Physicians who had attested to the sampled death certificates were sent a 5-page paper-and-pencil

questionnaire by the Flemish Agency about the medical decisions made at the patient's end of life, the decisionmaking process, and the care provided.

Inclusion criteria: have reported a death of a child between August and December 1, 2001.

Caring of a infants for newborns in group II (Patients and methods Intenviews, pF435): Group II : stabilised newborns with a poor prognosis

Nursing home physicians, who are employed by the nursing home in the Netherlands, completed questionnaires regarding their decisions and treatments at the time of deciding to withhold antibiotics.

We asked the pulmonologist or oncologist and the general

Pardon, K.Deschepper, R.Vander Stichele, R.Bernheim, J. L.Mortier F.Schallier, D.Germonpre, P. Galdermans, D.Van Kerckhoven W.Deliens, LEolic Consortium
We conducted a nationwide death certificate study in 2007 in Flanders, analogous to our death certificate study of 1998. The Flemish Agency for Care and Health selected a random stratified sample of all death certificates of persons ages 1 year or older from June to November 2007.

We conducted a nationwide death certificate study in 2007 in Flanders, certifcate study in 2007 in Flanders, study of 1998 . The Flemish Agency for Care and Health selected rand cer a random stratified sample of all death certificates of persons ages 1 year or older from June to November 2007

STUDY 1:Inclusion criteria: have died between August 1 and December 1 2001 in the Netherlands, aged between 1-17 years

"infants who died before the age of 2 months between October 2005 and September 2006 in the NICUs"

We identified eligible subjects from a nationwide Dutch study of 706 nursing home residents with dementia who were diagnosed with pneumonia. For the present analyses, we first selected the 165 (23\%) patients who physicians decided not patients who phyicians decided not Figure 1, we excluded 22 patients, including 12 who survived for 3 months and 8 who died of another cause or a second episode another cause or
of pneumonia.

Patients conformed to the following inclusion criteria: a recent initial diagnosis of non-small cell lung cancer (NSCLC) stage Illlb or IV, 18 yrs. or older, Dutch speaking and physically and psychologically able to participate and psychologically able to participate
in the study. The patients were $r$ in the study. The patients were $r$ ecruited consecutively during one year 13 hospitals in Flanders.
(Flanders)

(NSCLC patients) population of of euthanasia in advanced lung cancer patients practitioner (GP) of the patien

to fill in an after-death questionnai 18 months of inclusion in the study. 
Table 3 Variations in study methods for 39 jurisdiction-wide surveys and 22 included in analysis of practice variation (Continued)

Sweden $1998 \quad$ No $\quad$ Specific $\quad$ Palliative care, assisted suicide $2000 \quad$ Valverius, E.Nilstun, T.Nilsson, B. Inclusion criteria: Swedish

(Palliative care

population and euthanasia. Nationwide

Pharmaceutical Statistics OR

working in palliative care units in

Sweden OR members of the Swedish

physicians

Sweden 1998

(Association for

the Study of

No

Specific

Palliative care, assisted suicide

Pain Physicians)

population of and euthanasia: Nationwide

physicians

questionnaire to Swedish

physicians

2000

Valverius, E.Nilstun, T.Nilsson, B.

Association for the Study of Pain

Inclusion criteria: Swedish

Pharmaceutical Statistics OR

working in palliative care units in

Sweden OR members of the

Swedish Association for the Study

$$
\text { of Pain }
$$

Nava, S.Sturani, C.Hartl, S.Magni, Once approved by the ERS office, G.Ciontu, M.Corrado, A.Simonds, A. a formal letter was sent by e-mal to all of the participants in the census on the epidemiology of RICUs in Europe, performed in 2002, and all members of the ERS Respiratory Intensive Care Assembly to invite them to participate in the present study.

1) The questionnaire was

administered to GPs in New Zealand (in August and September, 2000). It asked for details on the

last death in the previous 12 months

for which the physician was the attendant doctor, and whether that physician had access to a

multidisciplinary palliative care team

2) There are approximately 3000

2) There are approximately 3000
practising GPs in New Zealand and

questionnaire was sent to 2602 on commercial mailing list.
Inclusion criteria: deceased during 1997

Inclusion criteria: deceased during 1997

The aim of this task force, conducted between May 1, 2005 and October 31,2005 , was to collect data regarding end-of-life decisions in RICUs and high dependency units (HDUs) within Europe by means of a prospective questionnaire.

Note: [1] the end-of-life surveys were identified by the jurisdictions of investigation, year of study and methods to identify physicians; $a=$ death certificate studies, $b=$ physician survey, $c=$ neonate or infant study; [2] Note: [1] the end-oflife surveys were identifed by the jurisdictions of investigation, year of study and methods to identify physicians; a = death certifate studies, b= physician survey, c= neonate or infant study; [2] the term "exclusion" meant the surveys excluded from statistical analyses with other surveys because of the focus on specific populations or geographic regions, [3] the article listed in the table was the one that used for data extraction; [4] the methods to identify physicians included death certificates, physicians (registries or associations), neonate/infants (patients or death certificates), or other specific patient groups; [5] the numbers sampling strata or subgroups; [7] selective reporting meant that not all results of a single study were reported in the article 
Table 3 Variations in study methods for 39 jurisdiction-wide surveys and 22 included in analysis of practice variation (Continued)

\begin{tabular}{|c|c|c|c|c|c|c|c|c|}
\hline Surveys [1] & $\begin{array}{l}\text { Methods to identify } \\
\text { physicians [4] }\end{array}$ & $\begin{array}{l}\text { Total number } \\
\text { of deaths } \\
\text { studied or } \\
\text { applicable [5] }\end{array}$ & $\begin{array}{l}\text { Clear } \\
\text { selection } \\
\text { criteria }\end{array}$ & $\begin{array}{l}\text { Data collection } \\
\text { method }\end{array}$ & $\begin{array}{l}\text { Practice } \\
\text { measurement } \\
\text { method }\end{array}$ & $\begin{array}{l}\text { Differential } \\
\text { response [6] }\end{array}$ & $\begin{array}{l}\text { Selective } \\
\text { reporting } \\
{[7]}\end{array}$ & $\begin{array}{l}\text { Response } \\
\text { rates }\end{array}$ \\
\hline $\begin{array}{l}\text { Netherlands } \\
\text { 1995a }\end{array}$ & Death certificates & 135675 & Yes & $\begin{array}{l}\text { Self-administered } \\
\text { postal questionnaire }\end{array}$ & Annual incidence & Uncertain & Yes & $77.0 \%$ \\
\hline $\begin{array}{l}\text { Netherlands } \\
\text { 1990a }\end{array}$ & Death certificates & 128824 & Yes & NA & Annual incidence & No & NA & $76.0 \%$ \\
\hline $\begin{array}{l}\text { Netherlands } \\
2001 \text { a }\end{array}$ & Death certificates & 140377 & Yes & $\begin{array}{l}\text { Self-administered } \\
\text { postal questionnaire }\end{array}$ & Annual incidence & Not reported & Yes & $74.00 \%$ \\
\hline $\begin{array}{l}\text { Netherlands } \\
\text { 1990b }\end{array}$ & Physicians & 128824 & Yes & Interview & Annual incidence & Yes & Yes & $68.0 \%$ \\
\hline $\begin{array}{l}\text { Netherlands } \\
\text { 2010a }\end{array}$ & Death certificates & 136056 & Yes & $\begin{array}{l}\text { Self-administered } \\
\text { postal questionnaire }\end{array}$ & Annual incidence & Yes & Yes & $74.0 \%$ \\
\hline $\begin{array}{l}\text { Belgium } \\
\text { (Flanders) } \\
\text { 2001/2002a }\end{array}$ & $\begin{array}{l}\text { EURELD-death } \\
\text { certificates }\end{array}$ & 55793 & Yes & NA & Annual incidence & No & Yes & $59.0 \%$ \\
\hline $\begin{array}{l}\text { Netherlands } \\
2001 \mathrm{~b}\end{array}$ & Physicians & 140377 & Yes & Interview & Annual incidence & Yes & Yes & $85.0 \%$ \\
\hline $\begin{array}{l}\text { Denmark } \\
\text { 2001/2002a }\end{array}$ & $\begin{array}{l}\text { EURELD-death } \\
\text { certificates }\end{array}$ & 58722 & Yes & NA & Annual incidence & No & Yes & $62.0 \%$ \\
\hline $\begin{array}{l}\text { Netherlands } \\
\text { 1994-1998 } \\
\text { (ALS patients) }\end{array}$ & ALS patients & 279 & Yes & $\begin{array}{l}\text { Self-administered } \\
\text { postal questionnaire }\end{array}$ & Annual incidence & No & Yes & $84.0 \%$ \\
\hline $\begin{array}{l}\text { Australia } \\
\text { 1996b }\end{array}$ & Physicians & 125771 & Yes & $\begin{array}{l}\text { Self-administered } \\
\text { postal questionnaire }\end{array}$ & Annual incidence & Yes & Yes & $64.0 \%$ \\
\hline $\begin{array}{l}\text { Sweden } \\
\text { 2001/2002a }\end{array}$ & $\begin{array}{l}\text { EURELD-death } \\
\text { certificates }\end{array}$ & 93755 & Yes & NA & Annual incidence & No & Yes & $61.0 \%$ \\
\hline $\begin{array}{l}\text { Netherlands } \\
\text { 2001/2002a }\end{array}$ & $\begin{array}{l}\text { EURELD-death } \\
\text { certificates }\end{array}$ & 140377 & Yes & NA & Annual incidence & No & Yes & $75.0 \%$ \\
\hline $\begin{array}{l}\text { Switzerland } \\
\text { (German- } \\
\text { speaking) } \\
2001 / 2002 a\end{array}$ & $\begin{array}{l}\text { EURELD-death } \\
\text { certificates }\end{array}$ & 44036 & Yes & NA & Annual incidence & No & Yes & $67.0 \%$ \\
\hline UK 2007/2008b & Physicians & 72071 & Yes & $\begin{array}{l}\text { Self-administered } \\
\text { postal questionnaire }\end{array}$ & Annual incidence & Yes & Yes & $42.1 \%$ \\
\hline $\begin{array}{l}\text { Italy } \\
2001 / 2002 a\end{array}$ & $\begin{array}{l}\text { EURELD-death } \\
\text { certificates }\end{array}$ & 22368 & Yes & NA & Annual incidence & No & Yes & $44.0 \%$ \\
\hline $\begin{array}{l}\text { Belgium } \\
\text { (Flanders) } \\
\text { 1998a }\end{array}$ & Death certificates & 56354 & Yes & $\begin{array}{l}\text { Self-administered } \\
\text { postal questionnaire }\end{array}$ & Annual incidence & Not reported & No & $64.8 \%$ \\
\hline $\begin{array}{l}\text { Belgium } \\
\text { 2005/2006a }\end{array}$ & Death certificates & 2690 & Yes & NA & Annual incidence & Yes & Yes & $64.3 \%$ \\
\hline
\end{tabular}


Table 3 Variations in study methods for 39 jurisdiction-wide surveys and 22 included in analysis of practice variation (Continued)

\begin{tabular}{|c|c|c|c|c|c|c|c|c|}
\hline France 2009a & Death certificates & 47872 & Yes & $\begin{array}{l}\text { Self-administered } \\
\text { postal questionnaire }\end{array}$ & Annual incidence & Not reported & Yes & $40.0 \%$ \\
\hline $\begin{array}{l}\text { Netherlands } \\
1990 \text { (Prospective) }\end{array}$ & Prospective & 128786 & Yes & $\begin{array}{l}\text { Self-administered } \\
\text { postal questionnaire }\end{array}$ & Annual incidence & Not reported & Yes & $80.0 \%$ \\
\hline $\begin{array}{l}\text { Netherlands } \\
\text { 1995b }\end{array}$ & Physicians & 135675 & Yes & Interview & Annual incidence & Not reported & Yes & $74.0 \%$ \\
\hline $\begin{array}{l}\text { Belgium } \\
\text { (Flanders) } \\
\text { 1999/2000c }\end{array}$ & Neonates/infants & 292 & Yes & $\begin{array}{l}\text { Self-administered } \\
\text { postal questionnaire }\end{array}$ & Annual incidence & Not reported & Yes & $87.0 \%$ \\
\hline $\begin{array}{l}\text { Netherlands } \\
\text { 2005a }\end{array}$ & Death certificates & 136402 & Yes & $\begin{array}{l}\text { Self-administered } \\
\text { postal questionnaire }\end{array}$ & Annual incidence & Not reported & Yes & $77.80 \%$ \\
\hline $\begin{array}{l}\text { Netherlands } \\
2001 c\end{array}$ & Neonates/infants & 1088 & Yes & $\begin{array}{l}\text { Self-administered } \\
\text { postal questionnaire }\end{array}$ & Annual incidence & Not reported & Yes & $84.0 \%$ \\
\hline $\begin{array}{l}\text { Netherlands } \\
2005 / 2006 \\
\text { (HGG patients) }\end{array}$ & HGG patients & 223 & Yes & $\begin{array}{l}\text { Self-administered } \\
\text { questionnaire }\end{array}$ & Annual incidence & No & Yes & $62.0 \%$ \\
\hline $\begin{array}{l}\text { Netherlands } \\
\text { 1995c }\end{array}$ & Neonates/infants & 1041 & Yes & $\begin{array}{l}\text { Self-administered } \\
\text { postal questionnaire }\end{array}$ & Annual incidence & Not reported & Yes & $88.0 \%$ \\
\hline $\begin{array}{l}\text { Belgium } \\
\text { (Hasselt, } \\
\text { Flanders) } \\
\text { 1996a }\end{array}$ & Death certificates & 970 & Yes & $\begin{array}{l}\text { Self-administered } \\
\text { postal questionnaire }\end{array}$ & Annual incidence & Yes & Yes & $55.0 \%$ \\
\hline $\begin{array}{l}\text { Belgium } \\
\text { (Flanders) } \\
2007 a\end{array}$ & Death certificates & 54881 & Yes & $\begin{array}{l}\text { Self-administered } \\
\text { postal questionnaire }\end{array}$ & Annual incidence & Not reported & Yes & $58.4 \%$ \\
\hline $\begin{array}{l}\text { Netherlands } \\
2005 / 2006 \\
\text { (Neonates/infants } \\
\text { (Aug to Nov)) }\end{array}$ & $\begin{array}{l}\text { Neonates/infants } \\
\text { (Aug to Nov) }\end{array}$ & NA & Yes & Interview & Annual incidence & Not reported & Yes & $97.80 \%$ \\
\hline Sweden 1998b & Physicians & 952 & Yes & $\begin{array}{l}\text { Self-administered } \\
\text { postal questionnaire }\end{array}$ & Annual incidence & No & Yes & $78.0 \%$ \\
\hline UK 2004b & Physicians & 22558 & Yes & $\begin{array}{l}\text { Self-administered } \\
\text { postal questionnaire }\end{array}$ & Annual incidence & Not reported & Yes & $53.0 \%$ \\
\hline $\begin{array}{l}\text { Netherlands } \\
2005 / 2006 \\
\text { (Neonates/ } \\
\text { infants (group I)) }\end{array}$ & $\begin{array}{l}\text { Neonates/infants } \\
\text { (group I) }\end{array}$ & 359 & Yes & NA & Annual incidence & Yes & Yes & $98.00 \%$ \\
\hline $\begin{array}{l}\text { Belgium } \\
\text { (Flanders) } \\
2007 \text { (Death } \\
\text { certificates } \\
\text { (cancer patients)) }\end{array}$ & $\begin{array}{l}\text { Death certificates } \\
\text { (cancer patients) }\end{array}$ & 15257 & Yes & $\begin{array}{l}\text { Self-administered } \\
\text { postal questionnaire }\end{array}$ & Annual incidence & Yes & Yes & $58.4 \%$ \\
\hline
\end{tabular}


Table 3 Variations in study methods for 39 jurisdiction-wide surveys and 22 included in analysis of practice variation (Continued)

\begin{tabular}{|c|c|c|c|c|c|c|c|c|}
\hline $\begin{array}{l}\text { Belgium } \\
\text { (Flanders) } \\
2007 \text { (Death } \\
\text { certificates } \\
\text { (non-cancer } \\
\text { patients)) }\end{array}$ & $\begin{array}{l}\text { Death certificates } \\
\text { (non-cancer } \\
\text { patients) }\end{array}$ & 39624 & Yes & $\begin{array}{l}\text { Self-administered } \\
\text { questionnaire }\end{array}$ & Annual incidence & Yes & Yes & $58.4 \%$ \\
\hline $\begin{array}{l}\text { Netherlands } \\
2001 \text { (Children } \\
\text { (1 to 17y) (Aug } \\
\text { to Dec)) }\end{array}$ & $\begin{array}{l}\text { Children (1 to 17y) } \\
\text { (Aug to Dec) }\end{array}$ & 610 & Yes & $\begin{array}{l}\text { Self-administered } \\
\text { postal questionnaire }\end{array}$ & Annual incidence & Not reported & Yes & $75.0 \%$ \\
\hline $\begin{array}{l}\text { Netherlands } \\
2005 / 2006 \\
\text { (Neonates/ } \\
\text { infants (group II)) }\end{array}$ & $\begin{array}{l}\text { Neonates/infants } \\
\text { (group II) }\end{array}$ & 359 & Yes & NA & Annual incidence & Yes & Yes & $98.00 \%$ \\
\hline $\begin{array}{l}\text { Netherlands } \\
\text { 1996-1998 } \\
\text { (Dementia in } \\
\text { nursing homes) }\end{array}$ & $\begin{array}{l}\text { Dementia in nursing } \\
\text { homes }\end{array}$ & 143 & Yes & $\begin{array}{l}\text { Self-administered } \\
\text { questionnaire }\end{array}$ & Annual incidence & No & Yes & $86.7 \%$ \\
\hline $\begin{array}{l}\text { Belgium } \\
\text { (Flanders) } \\
\text { 2007/2008 } \\
\text { (NSCLC patients) }\end{array}$ & NSCLC patients & 291 & Yes & $\begin{array}{l}\text { Self-administered } \\
\text { questionnaire }\end{array}$ & Annual incidence & Not reported & Yes & $91.3 \%$ \\
\hline $\begin{array}{l}\text { Sweden } 1998 \\
\text { (Palliative care } \\
\text { physicians) }\end{array}$ & $\begin{array}{l}\text { Palliative care } \\
\text { physicians }\end{array}$ & 122 & Yes & $\begin{array}{l}\text { Self-administered } \\
\text { postal questionnaire }\end{array}$ & Annual incidence & No & Yes & $83.0 \%$ \\
\hline $\begin{array}{l}\text { Sweden } 1998 \\
\text { (Association for } \\
\text { the Study of } \\
\text { Pain Physicians) }\end{array}$ & $\begin{array}{l}\text { Association for the } \\
\text { Study of Pain } \\
\text { Physicians }\end{array}$ & 130 & Yes & $\begin{array}{l}\text { Self-administered } \\
\text { postal questionnaire }\end{array}$ & Annual incidence & No & Yes & $82.0 \%$ \\
\hline $\begin{array}{l}\text { EUROPE } 2005 \\
\text { (RICU patients) }\end{array}$ & RICU patients & 6008 & Yes & $\begin{array}{l}\text { Self-administered } \\
\text { web questionnaire }\end{array}$ & Annual incidence & Yes & Yes & $21.5 \%$ \\
\hline $\begin{array}{l}\text { New Zealand } \\
2000 \mathrm{~b}\end{array}$ & Physicians & 693 & Yes & $\begin{array}{l}\text { Self-administered } \\
\text { postal questionnaire }\end{array}$ & Annual incidence & Uncertain & Yes & $48.0 \%$ \\
\hline
\end{tabular}




\section{Appendix 3}

Table 4 Coefficients of logit regression models for the frequencies of end-of-life practices

\begin{tabular}{|c|c|c|c|c|c|c|c|c|c|c|c|c|}
\hline \multirow[b]{3}{*}{ Variables } & \multicolumn{4}{|c|}{$\begin{array}{l}\text { 1. Withholding or withdrawal } \\
\text { of treatment }\end{array}$} & \multicolumn{4}{|c|}{$\begin{array}{l}2.1 \text { Use of opioids with possible } \\
\text { life shortening effects }\end{array}$} & \multicolumn{4}{|c|}{$\begin{array}{l}2.2 \text { Use of sedatives with possible } \\
\text { life shortening effects }\end{array}$} \\
\hline & \multirow[b]{2}{*}{ Coefficients } & \multicolumn{2}{|c|}{$(95 \% \mathrm{Cl})$} & \multirow[b]{2}{*}{$p$} & \multirow[b]{2}{*}{ Coefficients } & \multicolumn{2}{|c|}{$(95 \% \mathrm{Cl})$} & \multirow[b]{2}{*}{$p$} & \multirow[b]{2}{*}{ Coefficients } & \multicolumn{2}{|c|}{$(95 \% \mathrm{Cl})$} & \multirow[b]{2}{*}{$p$} \\
\hline & & $(2.5 \%$ & $97.5 \%)$ & & & $(2.5 \%$ & $97.5 \%)$ & & & $(2.5 \%$ & $97.5 \%)$ & \\
\hline Year & -0.002 & -0.003 & -0.002 & $<0.001$ & 0.044 & 0.043 & 0.045 & $<0.001$ & 0.101 & 0.098 & 0.104 & $<0.001$ \\
\hline \multicolumn{13}{|l|}{ Survey types } \\
\hline Death certificates & (reference) & & & & & & & & & & & \\
\hline Physicians & 0.94 & 0.92 & 0.95 & $<0.001$ & 0.02 & 0.01 & 0.04 & 0.01 & 0.58 & 0.55 & 0.60 & $<0.001$ \\
\hline Prospective & -0.14 & -0.16 & -0.12 & $<0.001$ & -0.17 & -0.19 & -0.15 & $<0.001$ & & & & \\
\hline \multicolumn{13}{|l|}{ Jurisdictions } \\
\hline Netherlands & (reference) & & & & & & & & & & & \\
\hline Australia & -0.39 & -0.41 & -0.37 & $<0.001$ & 0.59 & 0.57 & 0.61 & $<0.001$ & & & & \\
\hline Belgium & -0.20 & -0.33 & -0.06 & $<0.001$ & 0.00 & -0.11 & 0.11 & 0.98 & 0.13 & -0.04 & 0.29 & 0.13 \\
\hline Belgium (Flanders) & -0.19 & -0.20 & -0.17 & $<0.001$ & -0.10 & -0.11 & -0.09 & $<0.001$ & 0.44 & 0.42 & 0.46 & $<0.001$ \\
\hline Denmark & -0.34 & -0.37 & -0.32 & $<0.001$ & 0.13 & 0.11 & 0.15 & $<0.001$ & -0.86 & -0.92 & -0.81 & $<0.001$ \\
\hline France & 0.03 & 0.00 & 0.05 & 0.03 & -0.09 & -0.12 & -0.07 & $<0.001$ & & & & \\
\hline Italy & -1.71 & -1.77 & -1.64 & $<0.001$ & -0.27 & -0.31 & -0.24 & $<0.001$ & 0.42 & 0.37 & 0.47 & $<0.001$ \\
\hline Sweden & -0.34 & -0.36 & -0.32 & $<0.001$ & -0.15 & -0.17 & -0.13 & $<0.001$ & -0.61 & -0.65 & -0.57 & $<0.001$ \\
\hline Switzerland (German- speaking) & 0.53 & 0.51 & 0.55 & $<0.001$ & -0.09 & -0.11 & -0.07 & $<0.001$ & -0.19 & -0.24 & -0.14 & $<0.001$ \\
\hline UK & 3.28 & 1.57 & 4.99 & $<0.001$ & -0.41 & -0.44 & -0.38 & $<0.001$ & -204.15 & -209.97 & -198.32 & $<0.001$ \\
\hline
\end{tabular}

Table 4 Coefficients of logit regression models for the frequencies of end-of-life practices (Continued)

\begin{tabular}{|c|c|c|c|c|c|c|c|c|c|c|c|c|}
\hline \multirow[b]{3}{*}{ Variables } & \multicolumn{4}{|c|}{$\begin{array}{l}3.1 \text { Intentional use of lethal drugs } \\
\text { self-dministered by patients under } \\
\text { patient request }\end{array}$} & \multicolumn{4}{|c|}{$\begin{array}{l}3.2 \text { Intentional use of lethal drugs, } \\
\text { administered by professionals } \\
\text { under patient request }\end{array}$} & \multicolumn{4}{|c|}{$\begin{array}{l}3.3 \text { Intentional use of lethal drugs } \\
\text { administered by professionals } \\
\text { without patient voluntary request }\end{array}$} \\
\hline & \multirow[b]{2}{*}{ Coefficients } & \multicolumn{2}{|l|}{$(95 \% \mathrm{Cl})$} & \multirow[b]{2}{*}{$p$} & \multirow[b]{2}{*}{ Coefficients } & \multicolumn{2}{|c|}{$(95 \% \mathrm{Cl})$} & \multirow[b]{2}{*}{$p$} & \multirow[b]{2}{*}{ Coefficients } & \multicolumn{2}{|c|}{$(95 \%$ Cl) } & \multirow[b]{2}{*}{$p$} \\
\hline & & $(2.5 \%$ & $97.5 \%)$ & & & $2.5 \%$ & $97.5 \%)$ & & & $(2.5 \%$ & $97.5 \%)$ & \\
\hline Year & -0.049 & -0.056 & -0.042 & $<0.001$ & 0.016 & 0.014 & 0.018 & $<0.001$ & -0.057 & -0.061 & -0.053 & $<0.001$ \\
\hline \multicolumn{13}{|l|}{ Survey types } \\
\hline \multicolumn{13}{|l|}{ Death certificates } \\
\hline Physicians & 0.25 & 0.16 & 0.33 & $<0.001$ & 0.00 & -0.03 & 0.03 & 1.00 & 0.07 & 0.01 & 0.12 & 0.02 \\
\hline Prospective & 0.42 & 0.31 & 0.54 & $<0.001$ & 0.29 & 0.24 & 0.33 & $<0.001$ & 0.54 & 0.48 & 0.60 & $<0.001$ \\
\hline \multicolumn{13}{|l|}{ Jurisdictions } \\
\hline \multicolumn{13}{|l|}{ Netherlands } \\
\hline Australia & -0.94 & -1.13 & -0.75 & $<0.001$ & -0.18 & -0.22 & -0.13 & $<0.001$ & 1.59 & 1.54 & 1.65 & $<0.001$ \\
\hline Belgium & & & & & & & & & 1.36 & 0.97 & 1.76 & $<0.001$ \\
\hline Belgium (Flanders) & -0.17 & -0.31 & -0.02 & 0.03 & -0.72 & -0.77 & -0.67 & $<0.001$ & 1.59 & 1.55 & 1.64 & $<0.001$ \\
\hline Denmark & -0.94 & -1.28 & -0.60 & $<0.001$ & -3.69 & -4.03 & -3.35 & $<0.001$ & 0.29 & 0.19 & 0.40 & $<0.001$ \\
\hline \multicolumn{13}{|l|}{ France } \\
\hline Italy & -15.08 & -406.00 & 375.83 & 0.94 & -4.08 & -4.75 & -3.42 & $<0.001$ & -2.16 & -2.71 & -1.60 & $<0.001$ \\
\hline Sweden & -15.08 & -206.02 & 175.86 & 0.87 & -14.83 & -57.44 & 27.77 & 0.49 & -0.78 & -0.92 & -0.64 & $<0.001$ \\
\hline Switzerland (German- speaking) & 0.86 & 0.69 & 1.03 & $<0.001$ & -2.18 & -2.36 & -1.99 & $<0.001$ & -0.17 & -0.33 & -0.02 & 0.02 \\
\hline UK & -15.08 & -205.07 & 174.91 & 0.87 & -2.57 & -2.72 & -2.42 & $<0.001$ & -0.26 & -0.40 & -0.13 & $<0.001$ \\
\hline
\end{tabular}




\section{Abbreviations}

Cl: Confidence interval; CINAHL: Cumulative index to nursing and allied health literature; EMBASE: Excerpta Medica dataBASE; EURELD: European End-of-life Decisions Consortium; MEDLINE: Medical literature analysis and retrieval system online; PAIS: Public affairs information service; SCl: Science citation index; SSCl: Social sciences citation index

\section{Acknowledgements}

Amel Zertal contributed to the study coordination and data extraction. Stéphane Ratté developed the search strategy. Fin Finaud Consultats developed the FileMaker application for data management, with assistance from Richard Boivin. Geneviève Champagne and Pierre-Luc Pichette contributed to study identification and data extraction. Djamal Berbiche was consulted for analytical methods.

Participants in the Advisory Committee meetings included Jeff Blackmer (Canadian Medical Association); Marie-Dominique Beaulieu and Bill Sullivan (College of Family Physicians of Canada); Pierre Deschamps, Bernard Grenier, Ann Soden, and Robert Delorme (Canadian Bar Association); Jean Rodrigue, Jeanine Auger, and Louis Dufresne (Ministère de la santé et des services sociaux du Québec); Justine Farley and Danielle Drouin (Réseau des soins palliatifs du Québec); Ghislaine de Langavant (Commissaire à la santé et au bien-être du Québec). Some members of the advisory committee requested that their contribution remains anonymous. Researchers listed as authors remain sole responsible for the scientific integrity of the review and study conclusions, which do not necessarily reflect the position of the individuals and organizations represented on the Advisory Committee.

\section{Funding}

This project was funded by the Canadian Institutes of Health Research (grant number: 201304KRS-305414-KRS-CFDA-176304). AB is supported by a Canada Research Chair in Patient and Public Partnership, Canadian Institutes of Health Research clinician-scientist award and a Quebec Ministry of Health Family Medicine Research award. YSC was funded by a TD fellowship and the Centre de recherche - Hôpital Charles-Le Moyne (CR-HCLM). GG was sponsored by a scholarship from the CR-HCLM. PL holds a Canada Research Chair in Health Innovations.

\section{Availability of data and materials}

The data supporting the conclusions of this article are from the studies listed in Appendix 2

\section{Authors' contribution}

Protocol design: AB, IM, NM, PL, MCP, RP. Development of assessment criteria and extraction items: GG, YSC, AB; Execution of search strategy \& screening: YSC, GG, AB. Risk of bias assessment \& acquisition of data: YSC, GG, AB. Analysis of data and simulations: YSC. Interpretation of data: YSC, AB, IM. Manuscript preparation: YSC, AB. All authors have provided critical comments, read and approved the final manuscript. $A B$ and IM acted as co-principal investigators on the project. $A B$ is the guarantor. All authors have read and approved the final version of the manuscript.

\section{Competing interests}

All authors declared that they have no competing interests.

\section{Ethics approval and consent to participate}

The ethics committee of Universié de Sherbrooke Hospital Centre approved this study (project number: 14-066). No individual consent required for systematic review.

\section{Consent for publication}

Not applicable.

\section{Integrated knowledge translation}

An international advisory committee group of Canadian decision-makers provided input on the framing of the review question and classification of end-of-life practices, in order to increase the policy relevance of the review. The authors remain ultimately responsible for the scientific interpretation and conclusions.

\section{Author details}

'University of Montreal Hospital Centre Research Centre (CRCHUM), Montreal, Canada. ${ }^{2}$ Institut de recherche en santé publique de l'Université de Montréal, Montréal, Canada. ${ }^{3}$ Interdisciplinary School of Health Science, University of Ottawa, Ottawa, Canada. ${ }^{4}$ Université de Sherbrooke, Sherbrooke, Canada. ${ }^{5}$ Department of Health Services Research and Policy, London School of Hygiene and Tropical Medicine, London, UK. ' Département d'administration de la santé, Université de Montréal, Montreal, Canada. ${ }^{7}$ École nationale d'administration publique, Montreal, Canada. ${ }^{8}$ Scientific Institute for Quality of Healthcare, Radboud University Nijmegen, Nijmegen, The Netherlands. ${ }^{9}$ Département de santé publique de Montréal, Institut National de Santé Publique du Québec, Montreal, Canada.

Received: 31 March 2016 Accepted: 29 June 2016

Published online: 03 October 2016

\section{References}

1. Downar J, Boisvert M, Smith D. Data to support assisted dying. BMJ. 2014; 349(349): 94966.

2. Mcllroy GE. Some data on assisted dying from Oregon are worrying. BMJ. 2014;349(349):g4961

3. Suarez-Almazor ME, Belzile M, Bruera E. Euthanasia and physician-assisted suicide: a comparative survey of physicians, terminally ill cancer patients, and the general population. J Clin Oncol. 1997;15(2):418-27.

4. Delamothe T, Snow R, Godlee F. Why the Assisted Dying Bill should become law in England and Wales. BMJ. 2014;349(349):g4349.

5. Nicol J, Tiedemann M, Valiquet D. Euthanasia and Assisted Suicide: International Experiences, Parliamentary Information and Research Service, Editor. Ottawa: Library of Parliament; 2013.

6. Boivin A, et al. Comparing end-of-life practices in different policy contexts: a scoping review. J Health Serv Res Pol. 2015;20(2):115-23.

7. Steck N, et al. Euthanasia and assisted suicide in selected European countries and US states: systematic literature review. Med Care. 2013;51(10):938-44.

8. Battin MP, et al. Legal physician-assisted dying in Oregon and the Netherlands: evidence concerning the impact on patients in "vulnerable" groups. J Med Ethics. 2007;33(10):591-7.

9. Rietjens JA, et al. Medical end-of-life decisions: does its use differ in vulnerable patient groups? A systematic review and meta-analysis. Soc Sci Med. 2012; 74(8):1282-7.

10. Rietjens JA, et al. Two Decades of Research on Euthanasia from the Netherlands. What Have We Learnt and What Questions Remain? J Bioeth Inq. 2009; 6(3):271-83.

11. Onwuteaka-Philipsen BD, et al. Trends in end-of-life practices before and after the enactment of the euthanasia law in the Netherlands from 1990 to 2010: a repeated cross-sectional survey. Lancet. 2012;380(9845):908-15.

12. Griffiths J, Weyers H, Adams M. Euthanasia and law in Europe. Oxford: Hart Publishing; 2008

13. Marcoux I. Euthanasia: A Confounding and Intricate Issue, Euthanasia - The "Good Death" Controversy in Humans and Animals, Prof. Josef Kuře (Ed.), InTech; 2011. doi:10.5772/20184. Available from: http://www.intechopen. com/books/euthanasia-the-good-death-controversy-in-humans-and-animals/ euthanasia-a-confounding-and-intricate-issue.

14. Higgins JPT, Green S. Cochrane Handbook for Systematic Reviews of Interventions. In: Higgins JPT, Green S, editors. The Cochrane Collaboration. Chichester: Wiley; 2009

15. Moher D, et al. Preferred Reporting Items for Systematic Reviews and MetaAnalyses: The PRISMA Statement. PLoS Med. 2009;6(7):e1000097.

16. Morestin F, et al. Method for Synthesizing Knowledge About Public Policies. Québec: National Collaborating Centre for Healthy Public Policy; 2010.

17. Mays N, Pope C, Popay J. Systematically reviewing qualitative and quantitative evidence to inform management and policy-making in the health field. J Health Serv Res Policy. 2005;10 Suppl 1:6-20.

18. von Elm E, et al. The Strengthening the Reporting of Observational Studies in Epidemiology (STROBE) statement: guidelines for reporting observational studies. Bull World Health Organ. 2007;85(11):867-72.

19. Sanderson S, Tatt ID, Higgins JP. Tools for assessing quality and susceptibility to bias in observational studies in epidemiology: a systematic review and annotated bibliography. Int J Epidemiol. 2007;36(3):666-76.

20. Freedman VA, Martin LG, Schoeni RF. Recent trends in disability and functioning among older adults in the United States: a systematic review. Jama. 2002;288(24):3137-46. 
21. Helfand M, Balshem H. AHRQ series paper 2: principles for developing guidance: AHRQ and the effective health-care program. J Clin Epidemiol. 2010;63(5):484-90.

22. Higgins JPT, Altman DG, Sterne JAC. (editors). Chapter 8: Assessing risk of bias in included studies, in Cochrane Handbook for Systematic Reviews of Intervention. In: Higgins JPT, Green S, editors. 2011.

23. Beh EJ, Lombardo R. Correspondence Analysis: Theory, Practice and New Strategies, in Wiley Series in Probability and Statistics. Hoboken: Wiley; 2014.

24. Van Der Maas PJ, et al. Euthanasia and other medical decisions concerning the end of life. Lancet. 1991;338(8768):669-74.

25. Bilsen J, et al. Drugs used to alleviate symptoms with life shortening as a possible side effect: end-of-life care in six European countries. J Pain Symptom Manage. 2006;31(2):111-21.

26. Miccinesi G, et al. Continuous deep sedation: physicians' experiences in six European countries. J Pain Symptom Manage. 2006:31(2):122-9.

27. Rietjens JA, et al. Terminal sedation and euthanasia: a comparison of clinical practices. Arch Intern Med. 2006;166(7):749-53.

28. Sykes $N$, Thorns A. The use of opioids and sedatives at the end of life. Lancet Oncol. 2003;4(5):312-8.

29. Onwuteaka-Philipsen BD, et al. Trends in end-of-life practices before and after the enactment of the euthanasia law in the Netherlands from 1990 to 2010: a repeated cross-sectional survey. Lancet. 2012;380:908-15.

30. Chambaere $\mathrm{K}$, et al. Physician-assisted deaths under the euthanasia law in Belgium: a population-based survey. CMAJ. 2010;182(9):895-901.

31. van der Heide A, et al. End-of-life decision-making in six European countries: descriptive study. Lancet. 2003:362(9381):345-50.

32 Emanuel EJ. Euthanasia and physician-assisted suicide: a review of the empirical data from the United States. Arch Intern Med. 2002;162(2):142-52.

33 Seale C. National survey of end-of-life decisions made by UK medical practitioners. Palliat Med. 2006;20(1):3-10.

34 Seale C. End-of-life decisions in the UK involving medical practitioners. Palliat Med. 2009;23(3):198-204.

35 Deliens $\mathrm{L}$, et al. End-of-life decisions in medical practice in Flanders, Belgium: a nationwide survey. Lancet. 2000;356(9244):1806-11.

36 van der Heide A, et al. End-of-life practices in the Netherlands under the Euthanasia Act. N Engl J Med. 2007;356(19):1957-65.

\section{Submit your next manuscript to BioMed Central and we will help you at every step:}

- We accept pre-submission inquiries

- Our selector tool helps you to find the most relevant journal

- We provide round the clock customer support

- Convenient online submission

- Thorough peer review

- Inclusion in PubMed and all major indexing services

- Maximum visibility for your research

Submit your manuscript at www.biomedcentral.com/submit 